\title{
Phoebadius of Agen
}

Liber Contra Arianos

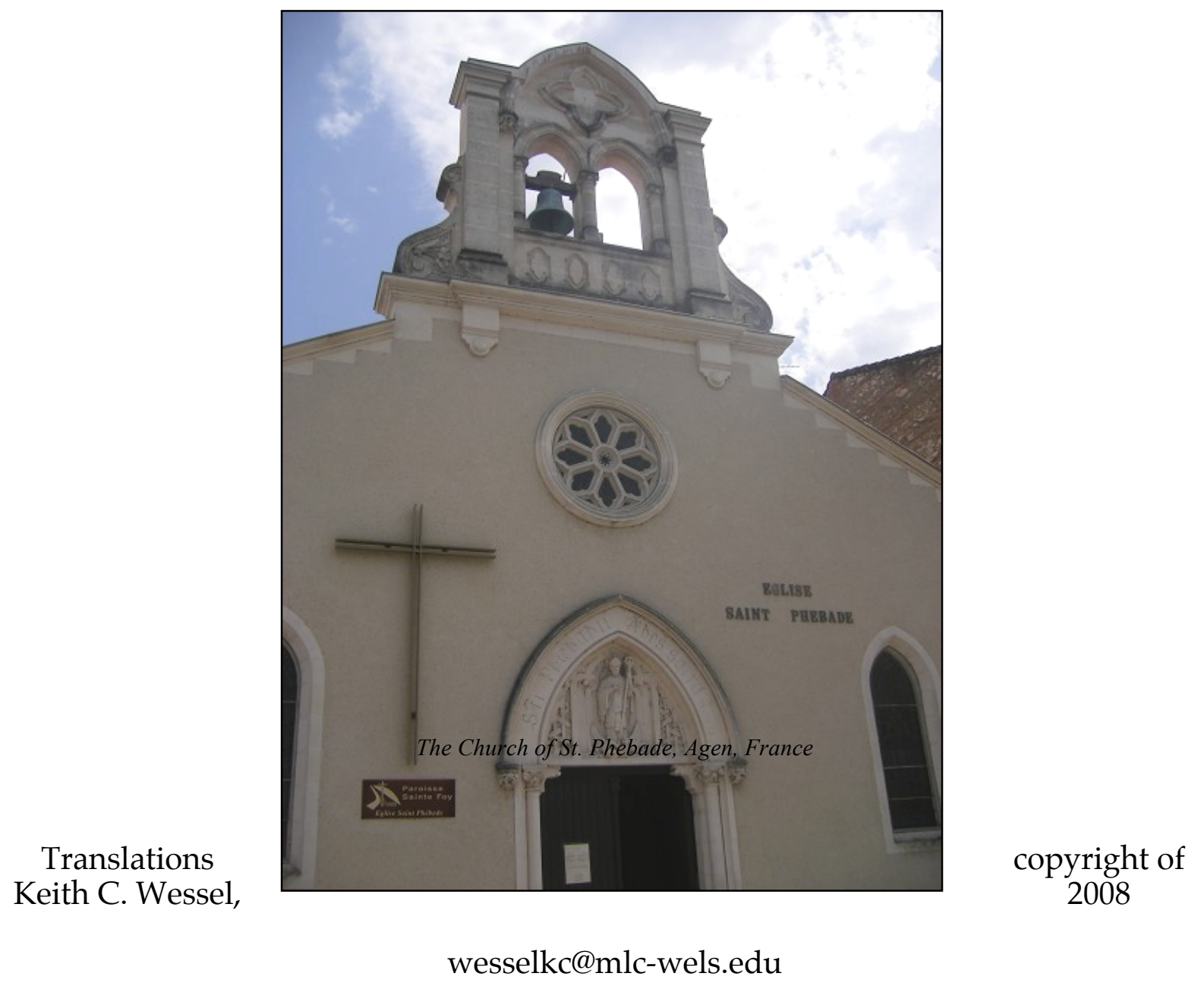




\section{FORWARD}

This present small contribution to the field of Patristics was generated throughout the first half of 2008 in fulfillment of graduate school requirements for the University of Florida.

At the date of this writing, no complete English translation of Phoebadius' Contra Arrianos exists. About half of chapter XXVII appears in English translation in Jurgens The Faith of the Early Fathers, Vol. 1 (Collegeville: The Liturgical Press, 1970). The most extensive research on Phoebadius is Peter P. Glaser's 1977 dissertation for the Univ. of Erlangen, Phoebadius von Agen. J. Draeske, over one hundred years ago, also penned the article Zu Phoebadius von Agennum, published in Zeitschrift fur wissenschafliche Theologie 33 (1890), p. $78 \mathrm{ff}$. Apart from these works, there is a paucity of scholarly information on Phoebadius.

Since this is so, I have also included here a translation of the Prolegomena to Phoebadius' work found in Migne's Patrologia XX. This provides the reader with sufficient background to understand the context of Contra Arrianos. Scholars of Migne's day attributed two other minor works to the bishop (also found in PL XX), and the rationale for this is provided in the Prolegomena. Modern textual criticism has undermined these arguments, and current scholarship (as noted in Dekker's Clavis) holds Contra Arrianos to be the only extant work of the Bishop of Agen.

Phoebadius' literary style is about what we would expect from Latin of Late Antiquity. Yet one can't help but notice that in many places Phoebadius has many ellipses which force the translator to supply words, even phrases, to continue the line of thought accurately and make the English flow properly. I leave it to others far more accomplished in Latin to judge how worthy my attempt is.

The Latin text used for the present translation is the one found in Corpus Christianorum, Series Latina LXIV (Turnholt: Brepols, 1985. p. 23-52.) Apart from a couple of places, the manuscript tradition is good and the variants, for the most part, are minor.

I am grateful to my advisor from UF, Dr. Kostas Kapparis, for his suggestions and encouragement, as well as to my colleague Prof. Joel Fredrich, who has, perhaps, forgot more Latin than I shall ever know.

KCW (Summer 2008) 


\title{
In the year of our Lord 400
}

\section{St. Phoebadius, Bishop of Agen}

\author{
(From A. Gallandius' Bibliotheca Veterum Patrum, Vol. V) ${ }^{1}$
}

\section{FORWARD}

Phoebadius was a Gaul by birth and, moreover, from the province of Aquitania - if we believe Sulpicius, ${ }^{2}$ who himself was Aquitanian and calls him "our Phoebadius." ${ }^{3}$ As St. Jerome writes, ${ }^{4}$ he presided over the church at Agen, the capital of the Nitiobriges, ${ }^{5}$ and was, perhaps, also born there. However, in precisely which year he was elevated to the office of bishop has not been researched at all. It certainly happened after the year 347 A.D., for he was not listed among the Gallic bishops who were present at the famous Council of Serdica in that same year, as Tillemontius ${ }^{6}$ and others have noted. But for certain he was distinguished in the episcopal order by the year 357 A.D., the same year that he, together with other Gallic bishops, rejected and condemned the second Sirmium Confession, sent into Gaul by Constantius II (the confession that Athanasius labeled as the "Seventh Arian Confession" and which Hilary also called the "blasphemy of Potamius and Hosius"). Moreover, he denounced it harshly with this present composition, as we can sufficiently ascertain from the work itself.

After his vigorous refutation, Phoebadius then attended the Synod of Rimini, convened also by Constantius in 359 A.D. With the exiled Fathers having not yet dealt with the matter, ${ }^{7}$ at this Synod Phoebadius certainly played a prominent role among those who

\footnotetext{
${ }^{1}$ [Printed in Venice, 1765-1781, and 1788 in 14 volumes.]

2 Sulpicius Severus (c.363 - 420/25) http://en.wikipedia.org/wiki/Sulpicius_Severus

${ }^{3}$ Sulpic. Sever. Hist. sacr. lib. II, c. 44

${ }^{4}$ Hieron. de Vir. illustr. cap. 108.

${ }^{5}$ [Caesar, in Bell. Gall. 7:7 (et. al.) describes this people as living in Aquitania, between the Garumna and Liger rivers. ]

${ }^{6}$ Tillem. Mem. eccl. tom. VI, p. 427; Sammarth. Gall. Christ. tom. II, p. 895: Histoire littéraire de la France tom. I, part. II, p. 266. [Louis-Sébastien Le Nain de Tillemont (1637-1698) was an ecclesiastical historian who wrote two monumental works, the Mémoires pour servir à l'histoire ecclésiastique des six premiers siècles and the Histoire des empereurs et autres princes qui ont régné pendant les six premiers siècles de l'Église. The first covers the history of the first six centuries of the Christian church, and the latter focuses on the history of the later Roman emperors. The twin brothers Scevole and Lewis (b.1571) co-authored the Gallia Christiana, left unfinished by the time of Scevole's death in 1650, and Lewis' in 1656. cf. Bibliotheca Britiannica, p.829. The Histoire littéraire de la France was begun in the eighteenth century by the Benedictines and the work was continued by the great French philologist Alexis-Paulin Paris (1800-81). The work was then continued by Paris' son, Bruno Paulin Gaston. cf. The Catholic Encyclopedia (C. Hebermann, New York: 1913) p. 498 ] ${ }^{7}$ Apparently Migne has in mind the exile of both Hosius of Cordova and Liberius, Bishop of Rome (352-66). Both were exiled in 355/56 when Hosius, nearly 100 yrs. old, sent a letter to the emperor asserting "the Western theory of
} 
took a stand for the catholic faith against the Arian faithlessness. Indeed, afterwards nearly all others compromised. But he, along with Servatius, bishop of Tongeren, ${ }^{8}$ contested most steadfastly for the truth of Nicea (as Sulpicius testifies ${ }^{9}$ ), enduring all the attacks of the Arian fanatics with an indomitable spirit. He even declared that he would prefer to undergo exile and all sorts of punishment rather than embrace a formula of the faith composed by the Arians. ${ }^{10}$

Yet deceived afterward by the fraud of Valens, he altered the formula as he saw fit. And since the altered version contained, in his view, nothing but catholic truth, he accepted this version and gave it support by his subscription. Of course Valens, the Arian bishop of Mursa, saw that the confession of faith asserted that Christ was not a "creation", so he added a clause of this sort, "as other creatures are." ${ }^{11}$ The poison of the Arian heresy was in that addition. As Sulpicius relates ${ }^{12}$, "For with these words he was saying that the Son was not similar to the rest of creation; nevertheless he was declaring that the Son was a creature, only greater than the others." I would like you to consider what St. Ambrose says about this matter. ${ }^{13}$

Accordingly, one could say that matters never reached a point at which Phoebadius joined in professing the Arian heresy. In fact, as soon as the fraud was discovered, Phoebadius himself and other Gallic bishops "condemned the actions of Rimini, and restored the faith of the churches to their original state," as Sulpicius states. Jerome is of

the Two Swords," i.e. that secular rulers have no authority over the Church, and vice-versa. Liberius supported Hosius. Cf. W.H.C. Frend, The Early Church. (Minneapolis: Fortress Press, 1982). p. 154-55.

${ }^{8}$ [d. 384 A.D. Tongeren was capital of the region of the Tongri (present day Belgium), and Servatius, now revered as a saint, was responsible for much of the spread of Christianity to the Low Countries.]

${ }^{9}$ Sulpic. Hist. sacr. lib. II, cap. 44.

${ }^{10}$ [Jerome wrote of the Synod of Rimini, "The world groaned and was astonished to find itself Arian." ]

${ }^{11}$ [ut sunt aliae creaturae is here in the Latin text of Migne. The full quote from Sulpicius' History runs thus: Dein conceptae a Faegadio et Servatione professiones edi coepere, in queis primum damnatur Arius, totaque ejus perfidia: caeterum non etiam Patri aequalis et sine initio, sine tempore, Dei Filius pronuntiatur. Tum Valens, tamquam nostros adjuvans, subjecit sententiam cui inerat occultus dolus: Filium Dei non esse creaturam sicut caeteras creaturas: fefellitque audientes fraus professionis. Etenim his verbis, quibus similis esse caeteris creaturis Filius negabatur, creatura tamen, potior tantum caeteris, pronuntiabatur. Ita neutra pars vicisse se penitus, aut victam putare poterat: quia fides ipsa pro Arianis, professiones vero postea adjectae pro nostris erant, praeter illam quam Valens subjunxerat, quae tum non intellecta, sero demum animadversa est. Hoc vero modo concilium dimissum, bono initio, foedo exitu consummatum. ( $P L X X$.)

The phrase in Migne's text, ut sunt aliae creaturae, seems to be a paraphrase of Sulpicius' sicut caeteras creaturas. Note that Phoebadius is here referred to as "Faegadio", and in his confession he makes it clear that the Son is entirely equal to the Father in every way. To this point Valens, Bishop of Mursa, added: "The Son of God is not a creature like other creatures." Calling this a deceptive language (fraus), Sulpicius condemns it. This is the sense the clipped Migne quote is to be understood.]

${ }^{12}$ Sulpic. Hist. sac. lib. II, cap. 44.

${ }^{13}$ Ambros. de Fide lib. III, c. 16, nn. 129, 130, opp. tom. II, p. 519. "Let him be accursed," say they, "who says

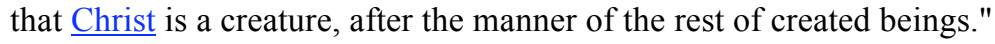

(http://www.newadvent.org/fathers/34043.htm ) 
the same opinion. ${ }^{14}$ This is further supported from historical records penned by Hilary $^{15}$ and Theodoret. ${ }^{16}$ Thus the holy bishop, vigorously attacking the error as soon as he first detected it, openly showed the soundness of his faith. For that reason, this incident took nothing away from his reputation, and his authority was not diminished in any way. For it is well-known that subsequently he presided at two different councils, both convened by the emperor Valentinian. The first was in 374 A.D. and the other in 380 A.D. ${ }^{17}$ He was still living in 392 A.D., as Jerome wrote in his book The Lives of Famous Men. There Jerome writes about Phoebadius: "He is still alive today, weakened by old age."18 Accordingly, he guided the church at Agen for about forty years. He was a man very well-known for his piety and doctrine, and was a most ardent opponent of the Arian faithlessness. For that reason he was even more dear than others to St. Ambrose, Bishop of Milan, as we understand from the latter's own letter addressed to both Phoebadius and Delphius, Bishop of Bordeaux, written at the same time. ${ }^{19}$ As for the rest, his memory is recollected in iconography ${ }^{20}$ at the church in Agen on April 25. Dionysius Sammarthanus ${ }^{21}$ and Bollandiani ${ }^{22}$ have additional information on this.

Furthermore, the great Doctor ${ }^{23}$ mentions one of the letters from those records which Phoebadius commended to posterity for the defense of the faith. But Jerome did admit that he had not read those remaining letters which were said to have been penned by the same author. ${ }^{24}$ He wrote, "He produced a book against the Arians. Other minor works are said to be his, which I have not yet read." But the book Against the Arians certainly is extant, and the blessed bishop wrote it in order to refute the second Formula of Sirmium that had been disseminated in Gallic regions by the Arians, translated into Latin, as Athanasius attests ${ }^{25}$, and which is also referred to by Hilary in his book ${ }^{26}$. This small work, along with many other writings of the ancients, was first published by Theodore Beza at Geneva in 1570; from there it passed into the libraries of the Fathers. Pierre Pithou included it with works by certain other old Gallic theologians and published the compilation in Paris in 1586. Furthermore, Caspar Barthius separately

\footnotetext{
${ }^{14}$ Hieron. Dial. adv. Lucifer., § 19, opp. t. II, p. 191 ed. Veron.

${ }^{15}$ Hilar. ex ep. hist. fragm. 11, num. 1.

${ }^{16}$ Theodor. Hist. Eccles. lib. II, c. 22.

${ }^{17}$ At Sargossa. Apparently Valentinian I convened the council of 374, and Valentinian II, the one in 380.

${ }^{18}$ Hieron. de Vir. illustr. cap. 108.

${ }^{19}$ Ambros. epist. 87, opp. tom. II, p. 1106.

${ }^{20}$ in pictis - Perhaps a reference to some sort of altar screen / painting.

${ }^{21}$ Sammarth. Gall. Christ. tom. II, p. 896.

${ }^{22}$ Bolland. Act. SS. April. tom. III, p. 366.

${ }^{23}$ [i.e. St. Jerome]

${ }^{24}$ Hieron. 1. c.

${ }^{25}$ Athan. de Synod., § 28, opp. t. I, part. II, p. 744.

${ }^{26}$ Hilar. de Synod. § 10.
} 
produced an annotated edition in Frankfurt in 1623. Then again at Paris in 1666, Delalandius saw to it that another edition was produced. However, the date for the composition of Against the Arians is, for good reason, estimated to be around the year 358 A.D., since Hosius of Cordova was still alive ${ }^{27}$, who had subscribed to the celebrated Formula of Sirmium, as we learn from the author himself ${ }^{28}$.

But our Bishop of Agen is reputed to have been the author of not only this one book. For we have just heard Jerome say that other minor works of his authorship had appeared in his own day which, nevertheless, he himself had not read at all. And even in our present day there exists another extant work, Concerning the True Faith: Against the Arians, a work which we, without any hesitation, recognize as a genuine product of Phoebadius' pen. We have arrived at that conclusion influenced in part by Jerome and in part by arguments of no small force which very erudite men have brought to light in support of the same opinion $^{29}$. A book of this kind is extant among the published works of Gregory of Nazianzus ${ }^{30}$ and Ambrose ${ }^{31}$, both of whom, nevertheless, should not be considered the author, as has been brilliantly demonstrated through the scholarly efforts of learned men ${ }^{32}$. And yet the opinions of those who reckon that the work ought to be ascribed either to Vigilius Tapensis or to Bishop Gregory of the see of Elvira, in the province of Baetica ${ }^{33}$ are considered equally unconvincing by these same illustrious scholars.

And they have excellent reasons for their views: both the style and context of the entire work openly proclaim a single author named Phoebadius ${ }^{34}$. Indeed, the author says as much at the very beginning of the piece: "A while ago," he states, "I had produced a small book against the Arians." Is there anyone at all who cannot see that these words refer to the earlier work, which is beyond a doubt that of Phoebadius, and has, in fact, such a title, just as Jerome designated the work? In addition, when comparing mannerism of speech, we find these in both works: in both works the Book of Wisdom is cited under the name of Solomon ${ }^{35}$, and the Nicene Symbol (Creed) is called the Nicene "Treatise" (Tract) in both ${ }^{36}$. The Sabellian heresy is linked to that of Arius ${ }^{37}$ in

${ }^{27}$ [ Hosius of Cordova died in 358 A.D.]

${ }^{28}$ Phoebad. lib. contra Arian. § 23, infra.

${ }^{29}$ Hist. litt. de la France, tom. I, part. II, pp. 273 seq.

${ }^{30}$ Greg. Naz. orat. 49, opp. tom. I, pp. 717 seqq.

${ }^{31}$ Ambros. append. tom. II, p. 346 edit. Paris. BB.

${ }^{32}$ Nourry ad Ambros. Append. 1. c.; Tillem. Mem. eccl. tom. IX, p. 727, not. 64, sur S. Grégoire de Nazianze; Histoire litt. de la France, l. c..

${ }^{33}$ [Gregorius Baeticus, Bishop of Elvira. d. 392 A.D.]

${ }^{34}$ Phoebad. de Fide orthod. c. 2. infra.

${ }^{35}$ Id., libr. contra Arianos, $\S \S 7,11$, pp. 251, 252; de Fid. orthod. c. 5. p. 261.

${ }^{36}$ Id., libr. contra Arianos, § 27, p. 256; de Fid. orthod. c. 8, p. 264.

${ }^{37}$ Id. ibid., § 13, p. 253; de Fid. c. 8, p. 264. 
both. Furthermore, both have the same teaching when they discuss the manner in which God manifested himself to the ancient fathers. Finally, in both there is the same interpretation of those passages of scripture where the distinction between the persons [of the Trinity] is discussed. You may see these and several other evidences investigated at greater depth by those who have written on Gallic literary history, whom we have just recently cited.

Furthermore, it also will be helpful to take note of something no one as of yet has observed: namely, that Phoebadius had the custom of publishing his own scholarly work anonymously, as he himself testifies when he says ${ }^{38}$, "he had given the Book Against the Arians to a friend for reading, at that same time he had strongly urged him to read it to wise and learned men without divulging the author; so that if anyone took issue with what seemed to be too strongly or too weakly expressed it in, it could be improved by the wisdom of many others." Thus he says. But the Holy Father would also do the same thing in publishing this work about which we are speaking. Indeed that is why, as appears correct to speculate, the occasion arose for ascribing such a work to Gregory of Nazianzus and Ambrose, those great fathers of either the Greek or Latin Church. Another result noted by scholars is that a fragment torn out of the same work of Phoebadius was bound together with a different book, Concerning the Unity of the Father and the Son, which is circulated among the works of Hilary of Poitiers ${ }^{39}$, as well as with a sermon that for the longest time they ascribed to Augustine ${ }^{40}$. And when we take into account all these factors, they convince us of both the antiquity and elegance of the work, while at the same time they demonstrate that the author was an exceptional man in respect to his teaching and scholarship.

For this little work we have reprinted the text which that most learned Benedictine monk, Nicholas Le Nourry (Nourryus), followed when he reviewed multiple manuscripts and ancient editions as he produced his outstanding edition of the works of Ambrose, in the Appendix to Vol. II, pp. 354-358.

What remains, then, is just a few words about The Handbook of Faith (Libellus Fidei), which holds third place among Phoebadius' works in our edition. For it is tantamount to an abridgement of the treatise that immediately precedes it, Concerning the Orthodox Faith (De fide orthodoxa). It belongs with the other book not only because of its similarity of material, but also because of the author's own design. Yet this handbook also exists among the orations of Gregory of Nazianzus (No. 50). Indeed, there already is

\footnotetext{
${ }^{38}$ Id. de Fid. orthodox. § 2, p. 257.

${ }^{39}$ Hilar. opp. tom. II, p. 719 ed. Veron.

${ }^{40}$ Aug. opp. tom. V in Append. serm. 113, pag. 206 ed. BB. Paris.
} 
agreement among scholars ${ }^{41}$ that this Oration No. 50, which is believed to be that of Nazianzen, resembles Oration 49 (which is similarly thought to be Nazianzen's work) to such an extent that it indicates one and the same author. So since it is clear enough from what was already said above, namely, that the author of Oration 49 is Phoebadius, for that reason Oration 50 should also rightfully be ascribed to him. But we don't have it in mind to pursue this matter any further. Whoever desires more let him consult the scholars whom we follow ${ }^{42}$. However, we have followed the latest edition of Ballerinius in our edition of this little book.

${ }^{41}$ Quesn. dissert. 14, ad opp. S. Leon., § 7, tom. II, pag. 380 ed. Lugd.; Baller. opp. S. Leon., 0013Btom. III, p. 945 ed. 1700 .

${ }^{42}$ Histoire littér. de la France, tom. I, part. II, p. 279, num. 3. 


\title{
The Book of Bishop Phoebadius ${ }^{43}$ Against the Arians
}

\author{
Chapter I
}

I.1. My dearest brothers:

I undoubtedly would not have had any correspondence about these things which have recently come to us in written form. ${ }^{44}$ But I saw through this devilishly subtle deception - a deception that had nearly taken over everyone's thoughts by [trying to] persuade us to believe that heresy actually is the correct faith and, in turn, to condemn the correct faith as heresy.

2. For it used to be sufficient (sufficiebat) for a pure conscience to hold on to what it believes, a conscience that judges that guarding one's own beliefs is more proper than to inquire about strange and foreign [ideas]. 3. But, as I have said, [I write] because we either have to permit heresy and propagate the illusion that we are in universal agreement (catholici) $)^{45}$, or we have to repudiate heresy so that we actually may be in universal agreement. So, of necessity, I yield (conscendo) to the task of writing this tract, in which this devilish virus, hidden under the modesty of pious reverence, summons ${ }^{46}$ us to publicly (in medium) denounce it. [We write this] so that evil, which hides under the opinion of honest words, may be detected, and so that truth, currently being gagged (interclusa), may breathe freely again by uncovering this falsehood. 4. These foreign

\footnotetext{
${ }^{43}$ Translation is made on the basis of the text in Corpus Christianorum, Series Latina LXIV. Turnholt: Brepols, 1985. p. 23-52.

${ }^{44}$ As noted in the Introduction, Constantius II had ordered the Second Sirmium Confession (cf. Appendix 1) to be circulated throughout Gaul for study and acceptance.

${ }^{45}$ I have chosen to translate catholicam as "universal agreement" here and wherever appropriate. In Phoebadius' mind, catholicam would mean agreement with the decision of Nicea - the only ecumenical council held to this point. In other places I simply employ the efficient term "catholic" with this understanding of "universal agreement."

${ }^{46}$ convenit - Given the various "legal" terms that flavor the opening of the piece (fraus, fides, damno) I have chosen a judicial flavor for convenio: "to summon before the tribunal," i.e. present evidence in a trial.
} 
ideas need to be destroyed so that we may hold to the truth. But I perceive that the truth won't be embraced unless these foreign ideas are first destroyed. Then people will trust in only those things that ought to be believed. ${ }^{47}$

5. And so I very much desire ${ }^{48}$ to be able to reveal this heresy to the public conscience, [this heresy] blind as it is with devilish deceit. Yet even as I debunk this heresy, [at the same time] I will also prove [to all] that I am in full agreement with universally accepted truth (catholicam). This gives security to my own faith. Indeed, I hope that [my agreement] is, first of all, proved to God, and then to my own conscience. But then I also need to prove [my catholicity] to those whom either ${ }^{49}$ fear or worldly ambition has not overcome..$^{50}$

\footnotetext{
${ }^{47}$ In $C C L$ the textual apparatus discusses the textual problems as this point. The Codex Voss, the oldest manuscript of Phoebadius ( $9^{\text {th }}$ cent.) has debeant for debeat. The passage in CCL reads thus: Destruenda sunt enim aliena ut nostris credatur. Nostris autem, nisi ea fuerint destructa ut solis credi debeat, non credendum video. But Migne reads: Destruenda sunt enim aliena ut nostris credatur. Nostris autem, nisi ea fuerint destructa ut solis credi debeat, non nisi credendum video. And the Beza manuscript of 1570, as reprinted in Dräseke (p. 88), reads: Destruenda sunt enim aliena ut nostris credatur. Nostris autem, nisi ea fuerint destructa ut solis credi debeat, nonnisi credendum video. Dräseke also reports the variant in Pithou's (1586) version: non ante credendum video. Finally, Barthius' (1623) edition reads non istis coni.

${ }^{48}$ ante - CCL's critical apparatus offers a number of suggestions to deal with this problematic ante. I have followed the suggestion of Migne: Ante haeresim - "Praemittendum videtur quamvis, vel quid simile." Quamvis seems to make the most sense here with the subjunctive possim. There is a sense of urgency in Ph.'s writing.

${ }^{49}$ Following $V$ (the oldest manuscript), CCL suggests $u t \ldots$ non vicerit, i.e. the purpose would then be to bolster fellow believers in their faith, and not to vindicate his own.

${ }^{50}$ If we read the text as printed in CCL, Phoebadius must have in mind "the faithful," i.e. true believers.
} 


\section{Chapter II}

II. 1. Therefore, since these ideas find their source in falsehood, not faith, and subsequently course their way throughout the entire body, we will prove that many [erroneous] things have been asserted (congesta) through the deception of this common confession. $^{51}$ We can't accept such things, of course. Some of them, in truth, have been asserted without any hint of shame.

2. For instance ${ }^{52}$, on the one hand they deceptively (non sine fraude) confess $^{53}$ that there is one God, and then openly deny that there are two Gods. But the term (nomen) "substance" is completely rejected, resulting in the Son being divided from the Father. 3. And then his birth is brought up (refero) ${ }^{54}$ as being "lowly." If they believe this (as they do) that [the Son came] in such a way - "lowly" -- from the Father, that has been sufficiently noted in their own confession. ${ }^{55}$. They insist that the Father is greater than the Son, yet greater not so much by some [internal] difference ${ }^{56}$, but rather in respect to all the good things (bonis) of the Father's divine glory is the Father held to be greater. But if the Son is less [than the Father] in respect to these [good things], then he himself cannot be considered worthy to be in the Father, since [the Father's] eternal blessedness accepts nothing into his own being (in semetipsam) unless it is of his own nature (proprium). Moreover, God has nothing in his own nature unless it is complete and perfect. So again, the Father cannot deem it worthy to be in the Son unless the Son is

\footnotetext{
${ }^{51}$ communis professionis - i.e. the "Blasphemy of Sirmium," 357 A.D. Cf. Appendix 1 for the text of the Seventh Arian (aka Second Sirmium) Confession.

${ }^{52}$ Here follow an introductory list of things the Arians were asserting that directly attacked the full divinity of Christ - which is the heart of the issue in the minds of Phoebadius and other pro-Niceans.

${ }_{53}^{5}$ propono - often used in syllogistic argumentation. et...nec (neque) - also used to emphasize contrasting ideas.

${ }^{54}$ refero - The nuance here, "to bring up for reconsideration." (Lewis / Short II.B.2)

55 i.e. the Arians emphasize the lowly birth of Christ as proof of his inferiority to the Father.

${ }^{56}$ differentia - Both Cicero and Gellius use the term in the sense of "specie" - a genus - which seems to be the sense here.
} 
able to have the entirety (totus) of the Father's being exist within him. $\mathbf{5}$. They deny that the Father had a beginning. But they emphasize this so that they may believe that the Son did not exist alongside the Creator (ad auctorem) but "in time" (ad tempus). ${ }^{57}$ However, I think that once you ascribe a "beginning" to someone, you automatically imply some sort of limitation on him. ${ }^{58}$ 6. Then they say that the Son is subject to the Father, not so much in the way as a son is subject to his father, but as a servant is to his master, as when we read: "A servant cannot be an heir." ${ }^{59}$ 7. Finally, [the Son] is referred to as being subject to the Father along with every other creature; the Father is described as invisible, immortal so that the Son, as is plain to see, is categorized along with things that are contrary to these [attributes of the Father.]

8. Thus if we refute these things one by one - not by human arrogance but rather with the authority of divine speech - it will logically follow that the universally accepted faith stands in part on this (in ea parte): it receives such a God - the kind of God who is who he ought to be. ${ }^{60}$

\footnotetext{
${ }^{57}$ hoc ideo ut Filius non ad auctorem se ad tempus habere credatur - lit. "this for the reason that it may be believed that the Son existed not from the Creator (Father) but from time". This jibes well with the well-known Arian maxim, $\pi \quad$ ("There was when he was not.") The Arians held that Christ existed before the creation of the world, i.e. before actual time began, but Phoebadius clarifies in the next sentence that even by saying ad tempus (virtual equivalent of the Greek - "the appropriate time") the Arians are implying some limitation on the nature of Christ, thus logically making him less than the Father.

${ }^{58}$ Puto autem cui initium sic adscribitur, fini obnoxious non negatur. The critical apparatus in the CCL text refers us to Hebrews 7:3 "Without father or mother, without genealogy, without beginning of days or end of life, like the Son of God he remains a priest forever."(NIV)

${ }^{59}$ Not a quote from either the $6^{\text {th }}$ or $7^{\text {th }}$ Arian Confessions $\left(1^{\text {st }}\right.$ and $2^{\text {nd }}$ Sirmium $)$. Rather, Ph. seems to be alluding to Paul's arguments in Gal. 4, which the Arians apparently have seized upon to prove their position.

${ }^{60}$ i.e. Faith accepts God in his "unreasonableness," for faith and logic must be set at odds when considering the nature of God. His nature is such that it beckons us to faith, and not understanding.
} 


\section{1. [Their confession] says, It is agreed that there is only one God. ${ }^{61}$ Certainly} here they don't appear to be presenting misleading inferences nor twisting the sanctity of simple faith with some malignant interpretation. 2. But one needs to be mindful of Ursatius and Valens and Potamius, ${ }^{62}$ because again and again they have confessed with sly deception a "unique" (unicum) God with these very same words. 3. I don't accept this expression of faith at face value, ${ }^{63}$ which on the surface gently coaxes in order to deceive the simple (imperitos) with heretical subtlety. They are out to lure away believers who are not on guard, just as someone might use honey to make a cup of poison seem harmless. ${ }^{64}$

4. It says: It is agreed that the one God is the omnipotent Father. None of us denies that, because no one is that ignorant. But since it is possible to examine their own writings, we say that they have confessed not so much "one God" as they have "one omnipotent Father." ${ }^{65}$ 5. For they do not wish the Son to be of the same unchangeable nature (constantia), and yet, nevertheless, they do confess that the Son is God. They won't refuse to accept that latter statement, but I think that when they say "one God" what they mean is "the entire (integrum) one God is the Father," and for that reason they say it in treachery, not in faith. 6. Although in the entire text (corpore) of

\footnotetext{
${ }^{61}$ At this point $\mathrm{Ph}$. begins a dissection of particular phrases found in the Arian creed, i.e. the Second Sirmium Confession (aka $7^{\text {th }}$ Arian Confession) that was circulating (at the emperor's order) throughout Gallic lands. The phrases of the Confession are indicated from this point on by bold type.
}

62 The Seventh Arian Confession (Second Sirmium) opens with these words: "Whereas it seemed good that there should be some discussion concerning faith, all points were carefully investigated and discussed at Sirmium in the presence of Valens, and Ursacius, and Germinius, and the rest. It is held for certain that there is one God, the Father Almighty, as also is preached in all the world." ( http://arian-catholic.org/arian/arian_confessions.html\#seventh )

${ }^{63}$ Nihil simplex in hac fidei professione suscepi.

${ }^{64}$ Perhaps there is an allusion here to Lucretius' famous metaphor of the doctor coaxing a young patient to take medicine by rimming the cup with honey. (D.R.N. IV. 10-25)

65 i.e. the words may sound the same to $\mathrm{Ph}$., but from other writings of the Arians $\mathrm{Ph}$. has concluded that their point of emphasis is different than that of the pro-Niceans; Ph. emphasizes "one God," and the Arians, "one Father." 
their confession they do not deny our Lord himself, in order to weaken [the meaning of the word] "God," they say that just as he is called by this name "God," just as we normal human beings are not unaccustomed to being called "Gods" [in Scripture]. "I have said, 'You are gods.' "66 And prior to that Moses was even called "God": "I will make you a god to Pharaoh."167

7. Therefore, lest anyone think that they have achieved a catholic confession with these words, [know this]: when we confess that the one God is Father, we also do not deny that the Son is God. For it is possible to refer to God the Father as "one God" in such a way that it really means "one Father," and not "one God." Likewise, it is possible to refer to the Son as "God" in such a way that [it is meant that] he is not God. 


\section{Chapter IV}

\section{1. [Their confession] says: It is not possible for there to be nor ought it be}

proclaimed that there are two Gods. We know this, and have we never confessed with our mouth that there are two Gods. For if God is not one and true, he is not God. 2.

But one needs to be aware in what sense that definition is put forward, for what treachery this entire [document] is prepared, and with what crime they fling out words that are more commonly used on our side (nobiscum). 3. For right after they say that, they provide the reason (ponunt) why they deny that there are two gods: "Because the Lord himself said, 'I am going to my Father and your Father, to my God and your God.' "68

But by such a definition [sprung] from a malicious interpretation, the Son is entirely separated from the Father and placed on a plane lower (infra) than the omnipotent God so that he can be united to us both the nature of his birth and the weakness of his humanity.

5. Then they attach this statement: Therefore there is one God of all things. But when they say that, they actually deny that our Lord [Jesus] is fully God. For [they are really saying that] he is placed under God the Father not by the name "Son" but rather by virtue of being a creature. ${ }^{69}$ 6. But, I believe, apostolic authority will be vindicated by the following passage, ${ }^{70}$ as Christ is said to be God more than he is ${ }^{71}$ : "And God gave him a name which is above every name. ${ }^{72}$ 7. But [here are passages they put forward] of the Lord himself denying that he is truly God: "This is life eternal that they may know you,

\footnotetext{
${ }^{68}$ Jn. 20:17

${ }^{69}$ Marius Victorinus especially addresses the terminology of the eternal generation of the Son in his treatises against the Arians, written shortly after Ph.'s tract. cf. Quasten, Patrology IV, p. 69-80.

${ }^{70}$ Hilary of Poitiers expounds on the Philippians passage and the mystery surrounding it in his De Trinitate IX.

71 i.e. more than the Arians say that the Son is

72 Php. 2:9
} 
the only true God. ${ }^{73}$ Or this: "Why do you say that I am 'good'? No one is good except God alone. ${ }^{\prime \prime 4}$ Besides these you hear: "Why do you not seek honor that comes from the one and only God?" 75 And, "Concerning that day and hour no one knows except the Father alone." 76

8. O blind guides! O worldly men deceived by ambition, who do not distinguish that the double state of lordly power is separate, each [retaining] its own respective properties! So whatever has been said about his human nature (de homine eius), you [also need to] join to $\mathrm{God}^{77}$, so that God himself is united to man in his $\mathrm{own}^{78}$ weakness.

${ }^{73}$ Jn. $17: 3$

${ }^{74}$ Lk. 18:19

${ }^{75} \mathrm{Jn} .5: 44$

${ }^{76}$ Mt. 24:36

77 adplicatis Deo - applico is more common with ad than with the dative, as appears here. Deo: no one denied that the Son was God. But I don't think Ph. has in mind "divine nature" here, set in opposition to "human nature." He intends to emphasize the fact that the Son is God.

${ }^{78}$ i.e. in man's own weakness 


\section{Chapter $V$}

V. 1. And for this reason you (Arians) want it to seem as if this double state is not a "joined" state but a "co-mingled" state, ${ }^{79}$ as even the writing of one of your men asserts, namely, The Letter of Potamius, which has been circulated throughout both the Eastern and Western churches. That letter says: When the flesh and spirit of Christ were mingled with the blood of Mary and reduced into one body, God was made capable of suffering. He says this lest anyone believe that he from whom he came [is capable of suffering], since there is enough agreement that He cannot suffer. ${ }^{80}$ 2. But the result is that you create out of the spirit of God and the flesh of man some kind of third creature, because he certainly isn't even God if he ceases ${ }^{81}$ to be the Word; for he [the Word] was made flesh. $^{82}$ Nor is he truly man because he was not properly flesh; for he was the Word. $^{83}$ 3. And in this way being made from each he is now neither. ${ }^{84}$ But I say that the one who stands against this poison is the one who has distinguished each respective substance on the basis of the property of emotion. 4. For the Spirit also performed his

\footnotetext{
${ }^{79} \mathrm{cmp}$. Tert. Adversus Praxean Liber 27.11: videmus duplicem statum, non confusum sed coniunctum, in una persona deum et hominem Iesum.

${ }^{80}$ Lingering around the entire Arian controversy is the genuine concern, mostly of Eastern churches, for slipping into Sabellianism, a monarchianistic teaching that would, logically, admit patropassionism, i.e. that since God is one monarch, he dons respective persona in his revelation to man, implying that the Father would have suffered along with the Son. Ph. guards against the idea that the Father is capable of suffering.

${ }^{81}$ Migne suggests desinit for the text's reading of desiuit.

82 caro enim factus est: Here, the indecl. form caro.

${ }^{83}$ The ellipses make Ph.'s argument difficult to follow at this point. It appears that this is his argument: Potamius had written that the spirit of Christ and the flesh of Mary combined to form Christ. But John 1 doesn't say "The spirit became flesh..." but "The Word became flesh..."

${ }^{84}$ Eutychianism would become full-blown in the mid-400's, closely linked to monophysite theology. Eutyches would view the incarnation as "paint mixing" i.e. red + yellow $=$ orange. This is precisely what $\mathrm{Ph}$. accuses Potamius of here, creating a third, unique substance that has lost the individual properties of the each of the combining elements.

$\mathrm{Ph}$. is following closely the argument of Tertullian in Ad. Prax.27: "For if the Word became flesh by a transfiguration and change of substance, it follows at once that Jesus must be a substance compounded of two substances-of flesh and spirit,-a kind of mixture, like electrum, composed of gold and silver; and it begins to be neither gold (that is to say, spirit) nor silver (that is to say, flesh),-the one being changed by the other, and a third substance produced. Jesus, therefore, cannot at this rate be God for He has ceased to be the Word, which was made flesh; nor can He be Man incarnate for He is not properly flesh, and it was flesh which the Word became. Being compounded, therefore, of both, He actually is neither; He is rather some third substance, very different from either. But the truth is, we find that He is expressly set forth as both God and Man;" ((Holmes translation, 1870 , in ANF 3. At www.tertullian.org )
} 
own deeds in him (Christ), that is, virtues and works and signs; and in the flesh Christ accomplished his sufferings. [For example], Christ longed for bread when he was being tempted by the devil; he thirsted at the well in Samaria, even though the prophetic voice had declared; The eternal God neither thirsts nor hungers. ${ }^{85}$ 5. And what can we add here about his human emotions? He wept [at the grave] of Lazarus ${ }^{86}$ as well as over Jerusalem. ${ }^{87}$ Later on he was anxious about the thought of his own death. ${ }^{88}$ But just because he demonstrated [his humanity] by his emotions, does that mean he never testified about it with his words? For he told Nicodemus, That which is born of flesh is flesh; and that which is born of Spirit is spirit. ${ }^{89}$ Or again, The flesh is weak, but the spirit is willing. $^{90}$

6. So then, the Spirit did not become flesh, nor did the flesh become the Spirit. The thing that those illustrious teachers desire is that from this co-mingling of substances, our Lord and God become capable of suffering. This is the reason why they want it to be said that he is capable of suffering, so that it won't be believed that he came from the one incapable of suffering. ${ }^{91}$

\footnotetext{
${ }^{85}$ Not a direct quote. But general sentiments about God's transcending of all human needs are expressed in such places as Is. 40:28 as well as Ps. 121:4.

86 Jn. 11:35

${ }^{87}$ Lk. 19:41

88 Jn. $12: 27$

${ }^{89}$ Jn. 3:6

${ }^{90}$ Mt. 26:41

${ }^{91}$ i.e. If one admits that Christ came from the one, true, impassibilis Deus, he shares the exact nature of the Father. The Arians wished to refute this.
} 


\section{Chapter VI}

VI. 1. But why do we need to examine these loftier teachings more closely? And how can we draw out this internal poison through our arguments - a poison now advancing so openly (prodeuntem communi)? How can we make it public by our judgment, when this light-shunning serpent, slithering his way through vague phraseology, and twisting along (just like he at times so frequently does) - when [this snake] reveals himself, and pours out in one big rush (pariter) all of his poison, when earlier he uses to just sprinkle it [here and there]?

2. From the bishops comes this pronouncement: "No one should speak of 'one substance.' "192 That is, no one in the Church ought to preach that the power of the Father and of the Son is one. What, then, did you accomplish, o men of blessed memory, who gathered at Nicea from all parts of the world and, after carefully studying the sacred rolls ${ }^{93}$ fixed the perfect rule of universal faith with such careful wording $(\text { sermone })^{94}$ ? There you gladly (bene) gave both the right hand of fellowship to those believing the common faith, as well as set up a formula of what is to be believed (formam credendi) to those in error. 4. But look at the result of your labor. Look where your anxious care has fallen -- the care with which you killed the seeds of rising evil, as much as was within your power at that time to do so. 5. Now it is forbidden in the Church to preach that very thing which you sanctioned for uncovering heresies- the only thing that ought to be preached in the Church! What you approved is now removed, and what you condemned is now brought in [to the Church], since falsehood is unable to establish itself (adstrui) except by the destruction of the truth. Indeed, that is

\footnotetext{
92 A directive stated openly in the Second Sirmium Confession.

93 i.e. of Scripture

94 The text has circuminspecto sermone here. Pithou suggests circumspecto - "to look anxiously at /for"
} 
not subject to destruction and will endure incorrupt forever, as it is [now]. Rather, just as if violated, [truth] punishes hands bearing in sacrileges against it. ${ }^{95}$

\footnotetext{
95 Textual notes here are many. Tertullian has a comparable phrase quasi violenta aliqua manus iniciatur [as if a hand is laid upon by someone doing violence...] When Ph. says violata, he must have in mind an attempted violation; otherwise the thought expressed in the previous sentence is undermined. This undoubtedly accounts, in part, for the textual problems at this spot.
} 
VII. 1. "No one should use the phrase 'one substance.'" What crime, what evil lurks in this statement? What part of it attacks the catholic faith? Is it assaulted by the character (sono) of the term or by the interpretation of the same? Unless I'm mistaken, the interpretation is faultless. 2. For "substance" indicates that which is always [comes] from itself; it is that which exists within itself by its own power. The one and only God [alone] has such power.

3. But I do not personally think that those who deny this are ignorant of the fact that this term (nomen) has a familiar usage in Scripture. For David says about the person of Christ: I have sunk in the deep mire, and there is no foothold (substantia). ${ }^{96}$ And again, My substance in the lower parts of the earth ${ }^{97}$ Again: My substance is always before me. ${ }^{98}$ Again: My substance is as if nothing before you..$^{99}$ Again: Let the creditor seize all his substance. ${ }^{100}$ 4. And Solomon uses it in the same way: Your substance ... and your sweetness... ${ }^{101}$ Also Jeremiah: If they had stood in my substance... ${ }^{102}$ And Proverbs: The substance of a rich man is a fortified city ${ }^{103}$ In the same book: Fathers divide their home and

\footnotetext{
${ }^{96}$ Translation is the NASB of Ps.68:3. The Hebrew word for substantia is dm'[ $\backslash \mathrm{m}^{\prime}$ - (ma-o'mād- $)$ "a foothold, standing ground"

${ }^{97}$ NASB: Ps. 139:15 "My frame was not hidden from Thee, When I was made in secret, And skillfully wrought in the depths of the earth." Heb. otzem, "strength", and Greek has - "bone"

${ }^{98}$ NASB: Ps. 38:8 "My hope is in you." - tl,x,AT (tônelet) - "hope." LXX has: $\pi$

$\pi \quad$. Ph. seems to be quoting from memory or working with a text with currently unknown variants; semper is found neither in the LXX or in the Hebrew text of BHS (Stuttgartensia).

${ }^{99}$ NASB: Ps. 38:6 - "And my lifetime as nothing in your sight." BHS has DIl.X,w "duration of life, the world," and LXX reads:

$\pi$

$\pi$

${ }^{100}$ NASB: Ps. 108:11 - "Let the creditor seize all he has..." BHS reads Al-rv,a]-lk'l - "all there is to him," and LXX reads, $\pi \quad \pi \quad$ - "all, as much as exists to him"

${ }^{101}$ From Apoch. Wisdom of Solomon 21:16. KJV - " For thy sustenance declared thy sweetness unto thy children..."

${ }^{102}$ NASB: Jer. 23:22 - "But if they had stood in my council..." The Vulgate does not even contain the word substantia in this place: si stetissent in consilio meo... Ph. seems to have in mind the LXX:

$\pi \quad$. BHS has the word ydIAsB - "in my council / assembly"

${ }^{103}$ NASB: Prov. 18:11 - "A rich man's wealth is his strong city," The LXX has a variant of $\pi$ again:

$\pi \quad \pi \quad \pi \quad$. BHS: AZ[u ty:r>qi ryvi[' ! Ah- "the wealth of a

rich man - a strong city."
} 
substance for their sons ${ }^{104}$ Then there is Tobit: If you will make an abundant substance for yourself... ${ }^{105}$ And again, My son, from your substance, give alms. ${ }^{106}$ 5. We also find the term used by John: The one who has the substance of the world... ${ }^{107}$ And also the Evangelist: Look, I am giving half of my substance.... ${ }^{108}$

6. I have collected all these example in one place so that this rumor (sermo) won't charm the unlearned, since some insist that the term "substance" ought not to be publicly preached about because that term can't be found anywhere in Scripture. ${ }^{109} 7$. But if the word "substance" itself is neither a novelty in the Scriptures nor has a faulty interpretation, it remains that we discover the actual reason why this term is being rejected. Upon closer inspection we find that they really aren't rejecting the term per se, but rather the quality (virtutem) of the term. 8. But if it [that quality] shines out, the whole reason for using that term in our writings (apud nos) will be evident ... as will the damage that their understanding of the term causes. For while they explore the novel roads of unholy intelligence, they have wandered away from the straight path of the gospel.

${ }^{104}$ CCL editors reference Prov. 13:22: Proverbs 13:22 bonus relinquet heredes filios et nepotes et custoditur iusto substantia peccatoris, but also Prov. 19:14 - domus et divitiae dantur a patribus a Domino autem proprie uxor prudens. NASB: Prov. 13:22 "... and the wealth (substantia) of sinners is stored up for the righteous.

105 Tobit 4:9 (KJV): " For thou layest up a good treasure for thyself against the day of necessity." VUL: si multum tibi fuerit abundanter tribue si exiguum fuerit etiam exiguum libenter inpertire stude. CCL editors suggest that Ph. is quoting Cyprian's Testimonia III.1 here.

${ }^{106}$ Tobit 4:7 (KJV): " Give alms of thy substance;" VUL: ex substantia tua fac elemosynam LXX: $\pi$ $\pi$

${ }^{107}$ NASB: 1 Jn. 3:17 : "But whoever has the world's goods..." UBS 4c : ...-where = "life, sustenance for life; goods"

${ }^{108}$ NASB: Lk.19:8 - "Behold, Lord, half of my possessions I will give to the poor." UBS 4c:

109 This explains the abundance of just-cited quotes. 


\section{Chapter VIII}

VIII. 1 However, before I go any further, the other side needs to defend those things that were publicly stated (proponuntur) ${ }^{110}$ in opposition to us. For they concede that the term "substance" can be found in the sacred rolls, but [they say] that doesn't automatically mean that it has the same nuance that we are convinced it has. For, according to them, as far as the term "substance" is concerned, it can indicate either "power" (virtutem) or "divinity." 111 2. But we who claim that the Father and the Son are of one substance, what are we to preach other than that in both, equally, exists the richness of the one divinity? Now concerning this richness the Apostle says, God has made well-known the riches of his glory, which is Christ. ${ }^{112} \quad 3$. We also say that this one "power" belongs to both. For the Apostle says as much when he states: Christ is the power (virtus) of God. ${ }^{113}$ Indeed this "power", since it needs no external assistance (indiget opis) is said to be "substance," as I said above: "whatever thing one has by himself." 4. So we insist that there is nothing novel, nothing strange, nothing inconsistent with "divinity" in this word, even if the word is quite often used figuratively. ${ }^{114}$ But, as I had begun to say, this search for another term is born entirely of their chagrin; it is not the term itself but rather the force (vis) of the term that bothers them. 5. For what ears could possibly welcome the proclamation that the Father and Son are of one substance - that is, one in honor, dignity, distinctness, power, and majesty, equally in both, truly held in common - how could they welcome this, those who separate the Son from the Father? What's more, after dividing the substances,

\footnotetext{
${ }^{110}$ Propono can also mean "to publish." It is unclear whether Ph. has in mind the official written documents of the Arians currently circulating throughout Gaul (cf. Ch. I), or merely just well-known public arguments of the Arians.

${ }^{111}$ But not both at the same time. Ph. pulls out more passages from Paul that demonstrate how the concepts of "power" and "divinity" cannot be nicely (even semantically) divided when it comes to the person of Christ.

${ }^{112}$ Col. 1:27

1131 Cor. $1: 24$

$114 \mathrm{Ph}$. is referring to the word virtus. The text reads: etiamsi in quamvis partem significantiae transferatur.
} 
they prefer that each exist with his own individual attributes, since they have completely dismissed the idea of a common divinity.

6. Right there you have the agitation behind their blasphemy; right there is the sacrilegious indignation that prompts their speech, namely, that the concept of one God allows both the Father and the Son [to be part of it.] 7. Even though the [original] authors of this poison are dead, their wicked teaching is not dead. For those authors, I say, separated the Son from the Father to such an extent that they publicly proclaimed these things with their sacrilegious mouths: "The Son of God certainly was created and brought forth before ages began, but he lived and existed, having been begotten by the Father, and had not existed prior to the time he was begotten." They also said: "He certainly is God... but not the true God." 8 . This teaching of one substance rightly displeases the followers of this treacherous lie (it is not a "belief") among whom the legacy of evil men slithers; they demand that this teaching be eliminated as if it were a scandal and responsible for fracturing Christian unity. But they are completely ignorant of the fact that we who say such things ${ }^{115}$ are entirely catholic, and are completely united in the common bond of this profession.

\footnotetext{
115 i.e. confessing the truth about the Trinity.
} 


\section{Chapter IX}

IX. 1 But who is able to endure this calmly, when they claim that Son definitely (pro certo) had a beginning, but then hold to the opinion that his birth is a matter of uncertainty? Either both things - the beginning and the birth - have to be regarded as secret, or both things ought to be recognized as something known, because they are contemporaneous events (contemporale); both things either have to both be known or both be unknown. ${ }^{116}$ 2. It states: ${ }^{117}$ The Son has a beginning, but the birth of the same is hidden. There's something not right about that statement, isn't there? Who reveals a beginning... and then is silent about the birth? Indeed, how did it happen that the birth itself is something that is known ... when it is claimed to be unknown? 3. But on this point, men who are entirely worthless will with good hope speak in defense of the statement (praescribunt) with the authority of the prophet who says: Who will tell of his birth? ${ }^{118}$ They don't understand that already at that time [the prophets] had foreseen, by prophetic spirit, those people who would to [try to] assign a beginning to the Word of God, that is, to the Son of God.

4. It states: Who will tell of his birth? That passage means this: his birth isn't able to be told about, so that you can't search for a beginning. 5. Who will tell of his birth? This means: no man will be able to tell of it. For no one was able except that one

\footnotetext{
${ }^{116}$ Alterum enim neque nosci neque ignorari sine altero potest. - Lit. "It is not possible both to know and be ignorant of one thing without the other." Ph. is saying this: the items are pairs; the beginning and the birth are both - together - either a known quantity or an unknown quantity. The Arians wanted one to be known, one to be unknown. Both $\mathrm{Ph}$. and Tertullian, from whom he borrows heavily, wrote in a pre-Vulgate world, and thus it appears that $\mathrm{Ph}$. uses navititatem in the sense of Jerome's generationem. In other words, $\mathrm{Ph}$. is not arguing about Christmas; rather he's referring to the eternal generation of the Son (cf. Ps.2) and not the incarnation. The Arians were apparently trying to make a distinction between two events that of necessity (according to $\mathrm{Ph}$.) are simultaneous (contemporale) events.

117 i.e. the Arian document circulating throughout Gaul, which $\mathrm{Ph}$. is scrutinizing in his defense of orthodoxy.

${ }^{118}$ Is. 53:8 - Vul. has generationem eius quis enarrabit. The form that $\mathrm{Ph}$. uses here, nativitatem, occurs only in the Vul. in 2 Macc. 7:23.
} 
who, explaining the inner heart ${ }^{119}$ of the Father, revealed chiefly to us the secret things about his own birth. 6. For we also read elsewhere something spoken in this same vein: Who has known the mind of the Lord? ${ }^{120}$ But again we are taught: [No one] except the Spirit who is in him. ${ }^{121}$ 7. Who will tell of his birth? This passage means: no one dares to tell of things he is not able to tell. And why will no one be able to tell? Because is it evident that He who lacks a birth is not only from him and with him, but also in him. ${ }^{122} 8$ Begotten from the Unbegotten, he was born with those attributes of the divine glory which were found within the Unbegotten. But this doesn't mean that because the Father begat him, he then ceased to possess those things that were within the same begotten one. Rather, he continues to have within himself the very same things that are in the one whom he begat. ${ }^{123}$ 9. For this reason his birth is said to be indescribable, because he was not conceived through it ${ }^{124}$ but the Son of God was brought about ${ }^{125}$ from God the Father. Thus we speak about Son what is according to the Scriptures: From him and with him and in him.

\footnotetext{
${ }^{119}$ Lat. sinus - Lit. "bosom," but used in Cl. Lat. metaphorically for "love, intimacy, hiding place, concealment."

${ }^{120}$ Ro. 11:34

${ }^{121} 1$ Co. $2: 16$

122 cf. 1 Co. 2:11 (NASB) "For who among men knows the thoughts of a man except the spirit of the man, which is in him? Even so the thoughts of God no one knows except the Spirit of God."

${ }^{123}$ Textual difficulties abound here. The Be (Beza) manuscript has perhaps the most logical solution by creating a new sentence: "Begotten from the unbegotten, he was begotten with all the good things of divine glory which the unbegotten One had within himself, and the begotten One has within himself. The Father has that which he begat, having the very same things within himself as in the one whom he begat."

${ }^{124}$ per ipsam - That is, that his "birth" marks some kind of beginning. V, Be, and Pi manuscripts suggest per ipsa here, without the non: "because he was conceived through these same things."

${ }^{125}$ perfectus est - It is difficult to choose a verb that does not in any way impose time constraints upon eternal mysteries. Ph. has to mean here not that the Son eventually was "finished," but rather he was, is, and always will be begotten of the Father.
} 


\section{Chapter X}

X. 1. Who is able to tell of his birth?, it says. And then they add this: "No one could make this known, since it was obviously known only to the Father." This is speaking with deceptive subtleties. Certainly the Father generated ${ }^{126}$ the Son, but no one knows whence (unde). In a similar way the Jews also argued, "We know that God spoke to Moses; but we don't even know from where (unde) this man is." 127 2. For although they, at times, use the same words as we do - and none of them appear to be, at face value (simpliciter), scattering abroad the disgraceful talk of crooked heresy - nevertheless because nearly all [of their talk] attacks the true faith, it is necessary to understand the few statements in light of the many. ${ }^{128}$ This is true especially when something that was embraced (receptum) was against the faith, it was entirely condemned by the faith.

\section{It also states: No one knows in what manner the Son was begotten except}

the Father alone. What does this statement signify? ${ }^{129}$ "Because the Lord [Jesus], not wishing us to be ignorant of this, said, I have come forth from the Father and from the bosom of the Father. ${ }^{130}$ " Good grief! Why wouldn't he want us to remain ignorant, chasing

${ }^{126}$ genuit - The more proper theological terminology is "generated" or 'begat", as opposed to "fathered" or some other word that implies a time element.

${ }^{127}$ Jn. 9:29

${ }^{128}$ necesse est secundum plura intellegi pauciora - Virtually a direct quote from Tertullian's Ad Prax. 2.20: "But I must take some further pains to rebut their arguments, when they make selections from the Scriptures in support of their opinion, and refuse to consider the other points, which obviously maintain the rule of faith without any infraction of the unity of the Godhead, and with the full admission of the Monarchy. For as in the Old Testament Scriptures they lay hold of nothing else than, "I am God, and beside me there is no God ;" so in the Gospel they simply keep in view the Lord's answer to Philip, "I and my Father are one;" and, "He that has seen me has seen the Father; and I am in the Father, and the Father in me." They would have the entire revelation of both Testaments yield to these three passages, whereas the only proper course is to understand the few statements in the light of the many. But in their contention they only act on the principle of all heretics. For, inasmuch as only a few testimonies are to be found (making for them) in the general mass, they pertinaciously set off the few against the many, and assume the later against the earlier. The rule, however, which has been from the beginning established for every case, gives its prescription against the later assumptions, as indeed it also does against the fewer." (http://www.christiandefense.org/Tertullian.Prax.htm\#20)

This hermeneutic principle appears in the church at an early date, that the clearer, more common testimonies are definitive, and shed light upon the lesser known and obscure passages of Scripture.

${ }^{129}$ volo + sibi $=$ "to mean, signify"

${ }^{130}$ An amalgam quote of Jn. 16:28 and Jn. 1:18. 
after the dark shades of ignorance as we are! It certainly wasn't his wish that we, after recognizing who the author of the statement is, would then start probing into the nature of his state of being. 4. For since we have come to understand where he was from, we then weren't supposed to probe into the matters of who exactly he is, or how he came into being, or what kind of being he is. But if this statement of the Lord himself is thrust before us as a proof passage, they will hear another [passage] from us so that they can't deceive [people] with divine definitions. For the one who spoke that passage also said this: No one knows the Father except the Son, nor does anyone know the Son except the Father. ${ }^{131}$ 5. And what follows right after that? And the one to whom the Son wishes to reveal [him]. This is not some deeply-hidden-away truth, because it is something that is able to be revealed. And it is revealed to anyone worthy of such revelation. 6 . This knowledge, which is revealed for a reason, is not something kept hidden for the sake of secrecy. It follows, then, that God - who punishes ignorance and cannot be regarded as unjust - should also punish us who are unworthy of such knowledge. But God does not punish if he has not given understanding. This he gives through his Holy Spirit. He says: The Spirit of truth will relate to you all truth. ${ }^{132}$ When he says, "all truth," he certainly means that nothing is left out.

\footnotetext{
${ }^{131}$ Mt. 11:27

${ }^{132}$ Jn. 16:13. Jerome's Vulgate has docebit for enarrabit.
} 


\section{Chapter XI}

XI. 1. This is the Spirit of wisdom and truth, through whom Solomon spoke about the Lord's generation (nativitate): What wisdom is and how it was made, I will tell you, and I will investigate it from its very beginnings (ab initio nativitatis). ${ }^{133}$ 2. Through this very same Spirit we also are able to learn what we wish to find out. The Apostle states: He will reveal to us [by] his Spirit. ${ }^{134}$ For the Spirit searches everything, even the deep things of God. No one knows what these things are in God except the Spirit of God. ${ }^{135}$ 3. This same Apostle goes on to show that if the Spirit lives in us, it is possible for us to implant inside ourselves, through the same Spirit, the secret things of God. [Jesus] said as much: Seek and you will find; ask and it will be given to you; knock and it will be opened for you. ${ }^{136}$ And again, Father ... those things which you have hidden from the wise and have revealed to little ones. ${ }^{137}$ 4. Indeed, it was to us that the Lord spoke when he said: To you it has been given to know the mysteries of God. ${ }^{138}$ To be sure, the Apostle speaks about this mystery: [The mystery] which was unknown to men of an earlier time, but now has been revealed to his saints. ${ }^{139}$ It was revealed openly; for he put on display the shining riches of his own glory in kindness upon those in Christ, because he himself is the glory of God the Father, ${ }^{140}$ the true offspring of the unbegotten One. 5. No one knows how the Son was begotten. No

\footnotetext{
${ }^{133}$ Wisdom 6:24. Again note at this very early date the exegetical tendency to equate the "Wisdom" of this passage and others (notably Prov. 9:1-9) as the personification of the Lord Jesus himself. Thus very early on, many of the references to wisdom in Solomon's corpus are viewed as messianic.

${ }^{134} 1$ Co. 2:10. The Greek expresses the agency more clearly:

$\pi \quad$. Jerome's Vulgate has per Spiritum suum.

${ }^{135} 1$ Co. $2: 10-11$

${ }^{136}$ Mt. 7:7

${ }^{137}$ Mt. 11:25

${ }^{138}$ Mt. 13:11 - Vul. has mysteria for Ph.'s mysterium. Paul, in Eph. 3, does use the term "mystery" as a collective truth concerning the entire salvific dispensation, but here it seems best to understand the term in the plural "mysteries" - as Jesus in the passage is explaining to his disciples the nature of his parables; the reference is to multiple truths about the Kingdom which Christ was proclaiming.

${ }^{139}$ Eph. 3:5 - In the context, the mysterium is the inclusiveness of the Gospel, i.e., that Jew and Gentiles are co-heirs with Christ, now joined together into one spiritual family.

${ }^{140}$ A combination of Eph. 2:7 and Col. 1:27.
} 
one does, to be sure ... that is, none of those (as the Lord said) who do not receive his word. They are just like those Jews to whom the Lord said: You do not know from where I come and where I am going because you make judgments according to the flesh. ${ }^{141} \mathbf{6}$. How can you say no one knows how this was done, when the Father himself says, My heart pours out a good word? ${ }^{142}$ No one knows how? The Son himself said: I have come forth from the mouth of the Most High. ${ }^{143}$ Don't explore the matter any further; you are not able to know what you are seeking after. Besides, you already know all there is to know, because what he said is the whole sum of it: I have come forth from the mouth of the Most High.

7. For his birth is the fulfillment of what I just said. ${ }^{144}$ This is the beginning without a beginning. This one appeared (ortus est) having a beginning in his birth, but not [a beginning] of his existence (in statu non habens). God came forth, one born from the unborn God; one God from one God, true God from true God, fully God from fully God. ${ }^{145}$ And by being born in this way, that is, with those eternal qualities (in his quae super erant), he did not at that point begin to be something that is born of things not conceived, nor was it a situation where a temporal existence was united to ${ }^{146}$ the timeless God through his nature. 8. For it is written: God is spirit. ${ }^{147}$ And: the eternal One was born of God. ${ }^{148}$ So this "eternalness" remains part of his nature. Therefore, the Son was not permitted to have an imperfect birth. Nor was He who begat him lessened

\footnotetext{
${ }^{141}$ Jn. 8:14-15.

${ }^{142}$ Ps. 44:2 (Vulgate), Ps. 45:1 in modern Bibles. Ph. takes verbum here as a reference to Christ.

${ }^{143} \mathrm{In}$ Ph.'s mind, the quote of Sirach 24:5 is apt, since the "word" comes out of a "mouth." The Vulgate quote runs thus: VUL Sirach 24:5 ego ex ore Altissimi prodivi primogenita ante omnem creaturam.

${ }^{144}$ The CCL editors capitalize Sermonis here, indicating a reference to the previous passage.

145 unus ab uno, verus a vero, plenus a pleno. Editors refer to Hil. De Trinitate II.8. " For He is the Offspring of the Unbegotten, One from One, true from true, living from living, perfect from perfect; the Power of Power, the Wisdom of Wisdom, the Glory of Glory, the Likeness of the invisible God, the ImageUnbegotten Father." (http://www.monachos.net/library/Hilary_of_Poitiers $\% 2 \mathrm{C}$ On the Trinity $\% 2 \mathrm{C}$ Book 2 )

146 congenitum $<$ congenero - a very rare word of this period.

${ }^{147}$ Jn. 4:24

${ }^{148}$ Jn. 1:13
} 
in some way, for he begat him from himself. For the All gave all, so that according to the Spirit's power he was all in all. ${ }^{149}$

149 cf. I Co. $15: 28$ 
XII. 1. These wicked teachers already are not confining themselves within the secrets of their own art, but now also take a stand against the truth with their own version of the truth; having horns like lambs but speaking as dragons. ${ }^{150}$ 2. And so in their desire to separate the Son from the Father and place him on a lower plane, they cite this passage from the Gospel: The Father is greater than I. ${ }^{151}$ And in what manner is he greater? Immediately they define how with heretical presumption: "[He is greater] in honor, fame, dignity, majesty. 3. But if this is so, why is it commanded that all may honor the Son just as they honor the Father? ${ }^{152}$ If this is so, then it follows that daily we are blaspheming in our thanksgiving ${ }^{153}$ and sacrificial offerings, since with them we confess that the Father and Son share these things in common. But, obviously, it isn't possible for the Son to have everything that rightly belongs to the Father, unless the Son himself is entirely in the Father. ${ }^{154}$ 4. For John says: No one has ever seen God except the only begotten Son who is in the bosom of the Father. ${ }^{155}$ And further on: All that is mine is yours, and all that is yours is mine. ${ }^{156}$ And: The Son is not able to do anything by himself. ${ }^{157}$ Again: I have not come to do my own will, but the will of the one who sent me. ${ }^{158} \mathbf{5}$. At any rate, these aren't confessions of his weakness, but rather declarations of his unity with the Father. For [Christ] had spoken against the concept of inferiority and emphasized his

\footnotetext{
${ }^{150}$ Rev. 13:11

151 Jn. $14: 28$

152 Jn. 5:23

153 in actionibus gratiarum - the actio gratiarum was an official term from the Roman world, a eulogistic speech delivered by candidates elected to public office.

${ }^{154} \mathrm{Ph}$. argues that by their (liturgical?) actions the Arians give thanksgiving and offerings to both the Son and the Father equally, and that shouldn't (couldn't) be unless the two are, in fact, co-equal.

$155 \mathrm{Jn}$. 1:18. Ph. seems to lay heavy emphasis on the Vulgates uses of the present tense here: nisi unigenitus Filius qui est in sinu Patris.

${ }^{156}$ Jn. 17:10

${ }^{157}$ Jn. 5:19

${ }^{158}$ Jn. 6:38
} 
unity with the Father when he said: He who sent me is with me. ${ }^{159}$ Or: The Father dwelling in me does his own work. ${ }^{160}$ And: The words I speak are not my own, but those of my Father. ${ }^{161}$ 6. So whatever is detracted from the Son also undermines the dignity of the Father. For the one does nothing without the other, since it isn't even possible for the one to do anything without the other. The Son isn't a son unless he has the Father, and the Father isn't a father unless he has the Son. 7. [Their confession emphasizes]: The Father is greater than I. But the fullness of his own divinity is within the Son. ${ }^{162}$ To this point the Apostle says: For whatever are the promises of God, they are in [Christ.] ${ }^{163}$ Do the many instances of obedience on the part of the Son then dissolve his divinity? [No.] ${ }^{164}$ 8. For everything that makes God to be God would then be dissolved in Christ if he acknowledges the majesty of another. ${ }^{165}$ And there certainly would be another, if the Father is greater than $\mathbf{I}$ in respect to majesty. But this majesty, since it is one (that is, belonging to the one God) cannot be imperfect. Imperfection implies inequality, and the majesty would be unequal if it were less in one of them. ${ }^{166}$

\footnotetext{
${ }^{159}$ Jn. 8:29

${ }^{160}$ Jn. $14: 10$

${ }^{161}$ Ibid.

162 cf. Col. 2:9, Heb. 1:3

1632 Co. 1:20

164 The previous question, introduced with numquid, expects a negative response.

${ }^{165} \mathrm{Ph}$.'s argument here is that if Christ the Son of God confesses his inferiority to the Father, then God ceases to be God, since (as $\mathrm{Ph}$. has shown) the two are actually one.

166 inaequalis autem si in altero minor est. - Referring here to Christ.
} 
XIII. 1. But if other passages are thrown against $\mathrm{us}^{167}$, namely, that Matthew uses the term "Son of Man" to emphasize [the Son's] plainness and inferiority, then read the same author when he says: The Son is going to come in the glory of his own Father. ${ }^{168}$ And about his coming Luke also records: When the Son of Man comes with his own glory and that of his Father. ${ }^{169}$ 2. For this reason our side does not say that the Son is less than God in majesty, because if this is said, then God himself is denied majesty. I point out what Solomon says about this: Splendor is of light eternal and an unblemished mirror of the majesty of God. ${ }^{170}$ Plainly, a mirror without blemish! 3. For he preserves (custodit) the face of God and then, faithfully representing (exprimens) the fullness of the Father's appearance (figuram), he reflected (reddidit) his image. ${ }^{171}$ And what more can we say about the state in which the Lord Christ perceived (agnovit) himself?

4. The Father is greater than I. Rightly said that he is greater, because he alone is the Source (auctor) without a source. But the Apostle says about the Son: Within him he has the fullness of divinity in a corporal manner. ${ }^{172}$ So, just as the Son is in the Father, so also the Father is completely in the Son. And our Lord, speaking about the Holy Spirit whom the Father promised [to send], added, He will take from what is mine. ${ }^{173}$ It is just as John has said: We proclaim to you eternal life, life that was with the Father, (and he adds) and

\footnotetext{
${ }^{167}$ in hoc loco... illud quod... - Singular, of course. But Ph. uses the singular substantive clause to encapsulate multiple usages in Mt. of the term "Son of Man." Mt. uses the phrase 29 x's in his Gospel.

${ }^{168}$ Mt. 16:27

${ }^{169}$ Lk. 9:26 - (cf. also Lk. 21:27) Ph. uses the passage to emphasize that the Son shares glory with the Father. But this is perhaps not the best proof passage, since the Greek goes on to read o[tan e; lqh $\mid$ evn th/| do,xh| auvtou/ kai. tou/ patro.j kai. tw/n a'gi,wn avgge,lwnÅ Arians could easily argue that the references to "angels' glory" only strengthens their point that a creature also can share glory.

${ }^{170}$ Sap. 7:26 - The context of the passage is a discussion similar to Prov. 8, where the author is extolling the virtue of "wisdom." This attribute of God was already at this point in exegetical history identified as being the Son, i.e. the pre-incarnate Christ.

${ }^{171}$ cf. Heb. 1:1-3, Col. 2:9

${ }^{172}$ Col. 2:9 (NIV) "For in Christ all the fullness of the deity lives in bodily form."

173 Jn. 16:15
} 
this life is in his Son. ${ }^{174}$ Indeed, if one is in the other and both are perfect, then the one perfect God is in two persons. ${ }^{175}$

174 Jn. 5:11

${ }^{175}$ CCL text has Ac sic. Multiple variants suggest a conditional statement here (si for sic, and sint for sunt.) I have chosen to follow the variants. Ph. isn't, of course, denying the Trinity here; he is simply trying to prove the point that the Son is equal to the Father in every way. 
XIV. 1. The Father is greater than I. Rightly said, because [the Father] himself did not descend into [the womb of] the Virgin - something Sabellius did not want, ${ }^{176}$ who made no distinction between the Father and the Son. ${ }^{177}$ He said that God has one person with two names, even though he heard the voice of the Father speak through Isaiah: Behold my Son whom I have chosen; I will put my Spirit on him. ${ }^{178}$ 2. And then through the same prophet Isaiah he should have recognized the Son himself speaking: The Spirit of the Lord is upon me because he has anointed me. ${ }^{179}$ Indeed, our Lord foresaw this heresy, and that is why he said: You do not believe that I am in the Father and the Father is in me. ${ }^{180}$ He certainly did not say: "I am the Father, and I am in myself." Rather, I am in the Father and the Father is in me. 3. In saying this, [our Lord] crushes two heresies: Sabellianism and Arrianism. For he taught that there is a Father and there is a Son; not one person as Sabellius [wished], nor two substances, as Arrius [wished]. Rather, he taught there is one substance and two persons, just as the catholic faith confesses.

\footnotetext{
${ }^{176}$ i.e. Sabellius did not want to divide the Godhead so that the Father could remain in heaven while the Son descended to earth. Modalistic monarchianism of the kind Sabellius taught arose from a genuine desire to profess the unity of God against what they percieved was a growing trend of over-emphasizing the persons of the Godhead.

${ }^{177}$ Lit. quod Sabellius noluit, apud quem Pater et Filius ambo non sunt [which Sabellius didn't want, with whom the Father and the Son are not a 'both']. Tertullian attacked Sabellianism (called "Patripassians" in the West) in his Adversus Praxean, refuting the modalistic monarchianism that lies at the heart of the error.

${ }^{178}$ Is.42:1. Prior to the passage the Latin reads: duum nominum una persona, cum Patris vocem adierit per Esaiam: The cum clause could be causal, in which case the Is. 42 passage is somehow a "proof passage" for Sabellius; or it could be concessive, in which case it become a tool in Ph.'s hand for refuting Sabellius. The latter seems more likely to me in the context seeing Sabellius seemed to have left no writings. Also, Tertullian in Ad Prax. 11.5 cites this very passage in refutation of modalism: "So absurd arid misleading a statement would be unworthy of God, that, widen it was Himself to whom He was speaking, He speaks rather to another, and not to His very self. Hear, then, other utterances also of the Father concerning the Son by the mouth of Isaiah: "Behold my Son, whom I have chosen; my beloved, in whom I am well pleased: I will put my Spirit upon Him, and He shall bring forth judgment to the Gentiles." (cited from http://www.christiandefense.org/Tertullian.Prax.htm\#11 )

${ }^{179}$ Is. $61: 1$, which Jesus in Lk.4:18 applied to himself.

${ }^{180} \mathrm{Jn} .14: 10$. Most Greek and English versions punctuate this as a question.
} 


\section{Chapter XV}

XV. 1. But why do we need multiple arguments when our Lord himself has given this definitive statement (sententia): Whatever the Father does, the Son also does the same things? 181 How could he do the same things unless he is able to aspire to the utmost (ad summam) of that paternal glory? 2. Because he is indeed able, John correctly states: Without him nothing was made. ${ }^{182}$ Moreover, the Lord himself said: I and the Father are one. ${ }^{183}$ They are one especially through their nature, since that which was in the Son of Man was also remaining in the bosom of the Father. 3. To prove the point: You neither know me or where I am from, nor [do you know] that I have not come on my own (non veni a me). But the one who sent me is true, the one you do not know. But I know him because I am with him, and he has sent me. ${ }^{184}$ Again: I am not alone, but I [am with] the Father who sent me. ${ }^{185}$ And: Just as the Father knows me and I know the Father. ${ }^{186}$

4. What's more, I don't know whether the Son was able to [truly] know the Father if the Son was allotted a beginning. For someone generated is not able to know the Ingenerate before he was generated. ${ }^{187}$ If that were the case, then he would not truly know the Father in the same way as he is known by the Father. He would then need to be considered to be a deceiver - something unbecoming of the Lord - and he would deservedly be called that if his proclamation could not withstand scrutiny

\footnotetext{
${ }^{181}$ Jn. 5:19

182 Jn. $1: 3$

${ }^{183}$ Jn. $10: 30$

184 cf. Jn. $7: 28$

185 Jn. 8:16

${ }^{186}$ Jn. 10:15

${ }^{187}$ Genitus enim nosse non potuit ingenitum, antequam genitus est. I've used the word "generate" (as opposed to "eternal generation", which is tantamount to "begotten") because $\mathrm{Ph}$. seems to be emphasizing temporal elements here. A variant reading has posse for nosse: "The generate is not able to be ingenerate..." In this argument that follows $\mathrm{Ph}$. has the Arians more in mind that the Sabellians. But it doesn't seem plausible that he has in mind Christ's birth in Bethlehem when he uses the word genitus. His whole argument in the previous sections has been to establish that the Son and the Father are co-equal, co-majestic, co-eternal - as is indicated by his closing remark to this paragraph, namely, to prove that the Son and the Father have always and mutually dwelt within each other.
} 
(ratione). On the other hand, it will not stand ... unless [what he said is true, namely that] he not only came from the Father, but is in the Father and was always in the Father.

5. He said, The Father has placed all things into [the Son's] hand. ${ }^{188}$ How could it [truly] be "all things" unless that also included the entirety of time ${ }^{189}$ ? And how could it include the entirety of time unless [the Son] has no beginning? As much as you insist that he was begotten (natum) before all time, nevertheless because you want for him to have begun at some point (i.e. someone who came into being, and had not always existed because he was made), I don't know how you can maintain that he has [been given] "all things" by the Father and yet came after the entirety of time.

\footnotetext{
188 Jn. 3:35

189 omnis temporis - Ph. is attacking this distinction that the Arians had made of the Son coming into existence "in time." But Ph. is arguing that when John writes "all things," that has to include everything, even all properties of time - or timelessness - itself. "All things" does not allow for a period when only the Father existed and the Son did not.
} 
Chapter XVI

XVI. 1. [Their confession] states: The Son is subordinate to the Father along with everything which the Father has subordinated to himself. ${ }^{190}$ What a poisonous virus you mask under the cover of such refined words! We, for our part, preach faithfully those things which we have heard from our fathers. But you have no desire to abandon the teaching of your ${ }^{191}$ fathers. 2. I tell you that these [teachers] have openly (libere) said that the God of heavenly glory "is not true God," but rather "is a perfect creature of God." Nevertheless you, thinking the same thing but avoiding words that plunge you into blasphemy, have purposely sought to use ambiguous words in order to deceive the simple-minded and unwary.

3. For you confess that the Son is subordinate to the Father not on the basis of the names "Father" or "Son" (as the holy catholic Church says), but on the basis of having the nature of a creature, as we have said above. For when you say, Along with everything which the Father has subordinated to himself, the Son is subordinate to the Father, are you not reckoning [the Son] to be one of the creatures (in creaturarum ordine) which were accordingly (ex tempore $)^{192}$ set in place? 4 . Thus, according to you, our God and Lord is regarded as nothing more than any creature, except that he was the first [thing created]; except that all these creatures also serve him - i.e. the creatures with whom he serves. To be sure, he himself is a servant if he serves. And since the Lord permits some things but [does others] according to his will, if the Lord was

\footnotetext{
${ }^{190}$ Quote from the $7^{\text {th }}$ Arian ( $2^{\text {nd }}$ Sirmium $)$ Confession, 357 A.D.

${ }^{191}$ i.e. your Arian teachers. Ph. employs the phrase patres vestri later in this same chapter.

192 ex tempore - It is difficult to understand why Ph. chose ex tempore here instead of in tempore ("in time"). One variant has instituta for institutae, rendering tempore instituta for creaturae institutae i.e. that "time" was established. Thus the argument would read: "...aren't you numbering [the Son] with the order of creatures which are part of the order of instituted time? Multiple manuscripts follow instituta. The variant reading probably makes better sense here.
} 
"made," it certainly was by the will of the Lord, and in being a servant he was doing what he was commanded to do.

5. This is what you have said secretly, and your fathers said openly: "The Son came forth from the Father outside of time (sine tempore), and had not been brought forth before he was generated (nasceretur)."193 6. What does that [reveal], I ask, except a dullness of the heart? What is this but a forgetting of hope? Indeed, what kind of mindless, blasphemous confession is this when you lump God [himself] in with all these [other] things that were made out of nothing? ${ }^{194}$ 7. If you say aloud that the Son is divine and yet deny this truth in your heart, what is that except making a mockery of the Son by giving him a false name? What is that but to label the Father as a liar as well, since he said, I am who I am. ${ }^{195}$ He also said, I am the only Lord, ${ }^{196}$ and My glory I will not give to another. ${ }^{197}$ Or again, Hear, O Israel, the Lord your God, the Lord is one. ${ }^{198}$ And, You do not inquire of my name; my name is the Lord. ${ }^{199}$ 8. Therefore, if God is one, this name ["God" (deus) ] belongs to the One (conpetit uni). It follows, then, that God will not be one unless God the Son is in God the Father. And rightly the prophet employed the name "Lord" in a similar manner when he said, Blessed is he who comes in the name of the Lord. ${ }^{200}$ For the Lord [Jesus] said, I have come in my Father's name. ${ }^{201}$ 9. Which name

\footnotetext{
193 cf. Hil. De Trinitate IV.13: "'So there are three Persons, Father, Son, and Holy Ghost. God, for His part, is the cause of all things, utterly unoriginate and separate from all; while the Son, put forth by the Father outside time, and created and established before the worlds, did not exist before He was born, but, being born outside time before the worlds, came into being as the Only Son of the Only Father."

(http://www.monachos.net/library/Hilary of Poitiers\%2C On the Trinity\%2C Book 4 ) Repeated verbatim in VI.6 of the same work.

I used "generated" for nasceretur because Christ's birth in Bethlehem is not what the Arians had in mind, but rather his coming into existence from the Father at some point sine tempore, i.e. outside the framework of creation / institution of time.

${ }^{194}$ i.e. the Creator Logos is part of and joined to the creation.

${ }^{195}$ Ex. 3:14

${ }^{196}$ Is. $43: 11$

197 Is. $42: 8$

${ }^{198}$ Dt. 6:4

${ }^{199}$ Latter half of the citation: Is. 42:8. The first half, perhaps a paraphrase of Is. 31:1.

${ }^{200}$ Ps.117:26 (English, Ps. 118:26)
} 


\section{of the Father [did Christ mean] unless it was the name of God and of the Lord? ${ }^{202}$ St.}

John, recognizing this about the Son, said [this about him]: He who is and who was and

who is to come, the Almighty. ${ }^{203}$

${ }^{201}$ Jn. 5:43

${ }^{202}$ In this treatise (and, apparently, in other literature of this time) the common practice has been to refer to the Father as Deus, and the Son as Dominus. Ph., in citing the passages he does, is arguing that in reality the names are interchangeable. Indeed, the prophecy of Ps. 118 - where the writer uses the name Domini - has to refer to the Father and not the Son, since the Son is the "one who comes." Ph. argues that the interchangeability of the two names points to the indwelling of each in the other, thus proving the Son's co-eternalness against the Arians.

What sparked this line of argumentation in the first place was a phrase that the Arian fathers themselves had used; they had referred to Jesus as the Filium Dei. (cf. XVI.5) Ph. argues that by using the name Dei, one has to concede that the Son shares in the immutable (cf. Ex. 3:14) divinity of the Father, since this name (Deus) is for the Father alone. To use the name and not believe it is to call the Son by a falso nomine, and to call the Father a liar in the process.

${ }^{203} \operatorname{Rev} .1: 8$ 


\section{Chapter XVII}

XVII. 1 [Your confession] states: The Father has no beginning. But that is to imply that the Son does. For why do you need to so carefully protect this well-known [truth] about the Father, unless it is a statement of prejudice against those who are of the opinion that this is equally true of the Son? 2. The Father has no beginning. Who denies this? But I think that the image of the God who is both invisible and limitless (ingenti) is not something that could have come into being at a later point. ${ }^{204}$ For God replied to an inquisitive Moses: I am who I always am. ${ }^{205}$ That is, he always was who he is and ever will be. 3. John speaks about this: What was from the beginning, we have seen with our eyes. ${ }^{206}$ And again, We have proclaimed to you life eternal which was with the Father $^{207}$, especially in the Father. For something that was "from himself" (ex ipso) is not something that is able to come "from outside himself (extra ipsum)." 4 . So it is accurately (sane) stated when it is said, Time was within him, ${ }^{208}$ not "He was proclaimed to have come to be 'in time.' "209 For the power of eternal life was not something that God manufactured; it was something that flowed out of himself. 5. So: I have come from the Father. ${ }^{210}$ And: I and the Father are one. ${ }^{211}$ Also this: He who has seen me has seen the Father, and, I am in the Father, and the Father is in me. ${ }^{212}$ This too: He who has sent me is with $m e .{ }^{213}$ Indeed, even David said, With you at the beginning on the day of your power. ${ }^{214}$ For

\footnotetext{
${ }^{204}$ imago...non potest coepisse post Deum. i.e. the imago Dei is bound up with God's eternal qualities, and therefore couldn't have come into existence at some later point (when the Father generated the Son, according to the Arians.)

${ }^{205}$ Ex. 3:14. Ph. adds the word semper when citing this ref., which is neither in the LXX or Hebrew text.

206 Jn. $1: 1$

${ }^{207} 1$ Jn. $1: 2$

${ }^{208}$ Erat in ipso tempus - The eds. of CCL speculate that this reference to an apparently well-known proverb may hint of Ambrose's De Fide IV.9.107. But that raises questions, since Ambrose isn't appointed bishop until 374 A.D., and Ph. writes $C A$ in the late 350 's.

${ }^{209}$ fuisse = "to have come into existence"

${ }^{210}$ Jn. 16:27

${ }^{211}$ Jn. 10:30

${ }^{212}$ Jn. 14:9-10

${ }^{213}$ Jn. 8:29
} 
the Word of God, that is, the Son of God, was before every beginning, with whom and from whom and in whom ${ }^{215}$-- the one who is unable to have a beginning.

7. Indeed, we find that Solomon has spoken about the person called "Wisdom," whom we maintain is Christ himself: The Lord established me and brought me forth before ages, and I was begotten prior to the depth(s). ${ }^{216}$ Therefore we ought not believe that God was "made." For if he was made, he was not; and if he was not, he will not be. So how can God, who possesses both states of being (conditio ${ }^{217}$ be described in such a way that he is not [truly] God? 8. This is why they proclaim the Wisdom of God was "born" (nata) and "established" (condita), so that it would not be believed that there was anything unborn (innatum) except God the Father himself, who is also the source of his own attributes (virtutibus suis). But Wisdom iscorrectly described, accordingly, as having been formed from him and in him, and that from him and by him this blessed, only-begotten generation (nativitas) pours forth.

\footnotetext{
${ }^{214}$ Ps. 109 (110):3. The Vulgate follows the LXX here for principium: h` avrch. evn h`me,ra| th/j duna,mew,j sou The Hebrew text here has, historically, been very problematic for exegetes. One commentator writes: "The last part of v. 3 is difficult to translate. Very literally it reads, 'Your people / willing [offerings] / on the day of your power, / splendors of holiness, / from the womb of the dawn, / to you dew of your youth.' The difficulty of the verse has produced several variant readings ... 'With you is the rule [i.e. princely dignity] in the day of your power in the splendor of your holy ones. From the womb before dawn I have begotten you' (reading ^yt,dul.y: ). It is noteworthy that the Hebrew OT Textual Project recommends a reading close to this. This reading makes God the speaker of the verse. The subject of the verse then is the birth of God's Son. This verse thus parallels Ps. 2:7. This is an appealing interpretation since it is strikingly messianic. However, it is not referred to in the New Testament, and the church fathers do not quote is as messianic before the time of Justin in the mid-second century. It, therefore, seems safest to stay with the Masoretic text." (J. Brug: A Commentary on Psalms 73-150. Milwaukee: Northwestern Publishing House, 2004. p. 287-88)

${ }^{215}$ Ro. 11:36

${ }^{216}$ Prov. 8:22/24. Glaser (p.150) points out that this was a favorite proof passage of the Arians. "Depths" is more reflective of the Hebrew plural ta_chom, but the Vulgate has the singular abysso. Indeed, one variant $(V)$ has the plural abyssos. genita sum - Fem., referring to sapientia. "Begotten" is the best rendering here for the flow of Ph.'s argument.

${ }^{217}$ i.e. erat and erit
} 


\section{Chapter XVIII}

XVIII. 1 Therefore, the one ${ }^{218}$ who maintained that the Father was, at some point, without the (W)word, without $(\mathrm{W})$ wisdom, without reason, without virtue, without the (S)spirit - that man maintained that the Son was not with the Father and in the Father before any beginning. 2. But I don't know how the Father can be called God, if he lacks all these attributes (virtutibus). For not only will God, who in his own eternal [nature] is perfect, be incomplete, so also will anything he would create after his own kind. ${ }^{219} 3$. For he is not able to be something he is not; nor will he be if he also lacked what he ought to be. ${ }^{220}$ Thus if the Father was missing even a small portion of completeness ( $s i$ aliquid defuit a toto), then he lacked completeness (totum). What's more, the Father then was deficient if his own Son (that is, the fullness of all [the Father's] attributes) had a beginning.

4. We need to understand that this "opinion," with its profane and sacrilegious way of defining things, crosses over onto one of two paths of blasphemy. Either one needs to believe that the Father had been allotted a beginning along with his own Son, since without the Son (that is, without his own attributes) he is not able to exist. (And, I suppose, then some kind of third God would have to be the source of their ${ }^{221}$ beginning.) 5. Or the other path is this: if it is said that the Father alone is without a beginning, then it needs to be maintained that he was imperfect up to the time of the generation of the Son. He would have to be [considered] imperfect, if [the Father]

\footnotetext{
${ }^{218}$ Rel. clause of characteristic. Either referring to Arius himself or the type of teachers who followed in his wake.

${ }^{219}$ A Fut. More Vivid condition, "expressing what will be the logical result." (AG 516.1) Ph's reasoning: if God is lacking the Son - who is the fullness of his virtutes - then the Father, prior to the Son's generation, lacked virtutes. Thus being incomplete (imperfect) prior to the Son's generation, it would have been impossible for the Father to generate anything perfect.

${ }^{220}$ i.e. God can't "become" God through some developmental process; he either is God or he isn't. Again, the FMV construction emphasizes the logical elements of the argument, not the "time" elements.

${ }^{221}$ i.e. of both the Father's and the Son's beginning, since Ph. has shown that the two, of logical necessity, had to either 1) always have existed together or 2) come into existence at the same time. But \#2 is patently out; the Arians have put in their confession Patrem initium non habere - something that the universal church also confessed.
} 
began to posses [at that point] what he did not previously possess ${ }^{222}$ yet ought to have and, [being God] wished to have. For one who is perfect ought to have always been perfect, and ought to have always possessed everything [for being perfect]; for [God] does not take into himself an increase of something he [already] possessed in its entirety.

222 i.e his "attributes" (virtutes), which Ph. has been fully identifying with the person of the Son, probably on the basis of Col. 2:9. 


\section{Chapter XIX}

XIX. 1 [Their confession] states: The Father has no beginning, being invisible, immortal, incapable of suffering. Here again they purposely state it this way so that they can assign to the Son [descriptions] that are the opposite of these. For whatever they do not [explicitly] say about the Father, they confess about the Son. And if it can be proved that the latter has a beginning, then - rightly so - they describe him as mortal, capable of suffering, etc.

2. But with the initial design of this proposition ruined (which assigned a beginning to the Word of God), there ought to have been a judgment ahead of time (praeiudicium) that the other kinds of sufferings are not appropriate for the Son.

Nevertheless, let us go over again those items that have been so impiously proposed, so that what I proclaim won't be viewed with mistrust. 3 . For if we cannot ascribe other things subject to this limitation as to the one not having a beginning, and it is discovered that there is [in fact] a mutual sharing of one of these, then it is reasonable to undermine also those things that had been championed. 
XX. 1 [Their confession] states: The Father is invisible. As if, for instance, we could discover that the Son was visible in any way before his transformation. ${ }^{223}$ That is to say, that even before he became obedient to the Father he was, in eternity, visible in bodily form. 2. For although he was seen by Abraham, by Jacob, by Moses, by Isaiah and Ezekiel, nevertheless the nature of [these appearances] was that he appeared in a vision. For we're told that he was seen in a dream, or in a reflection (speculo), or in some kind of symbolic representation (aenigma). Even Moses, asking if he could see [God] in a recognizable way (cognoscenter) was told: No one is able to see my face, for no one can see my face and live. ${ }^{224}$

3. Thus regarding this passage, let them earnestly assert that either the Father was speaking (the one who says that he is invisible) or, if they do not deny that the Son $^{225}$ was speaking at that time, let them know that he was invisible in his own name as Discourse ${ }^{226}$, as Spirit. ${ }^{227}$

\footnotetext{
${ }^{223}$ tranfiguratione - But not a ref. specifically to the Transfiguration of Jesus in the Gospel accounts (e.g. Mt. 17). $\mathrm{Ph}$. is making a point about the nature of the pre-incarnate Christ. His point is to prove that the Son also shared in the Father's attribute of invisibilis, and if so, then he is fully God, sharing in the attributes of God. Ph. states that the Arians implied that the Son lacked such attributes by the way they worded their confession.

${ }^{224}$ Ex. 33:13

${ }^{225}$ Tertullian, in Ad. Prax. XIV, directly addresses questions about the nature of theophanies in the OT. Specifically to Ph's. line of thought: "Either way, the Scripture misleads us, when it makes God invisible, and when it produces Him to our sight. Now, then, He must be a different Being who was seen, because of one who was seen it could not be predicated that He is invisible. It will therefore follow, that by Him who is invisible we must understand the Father in the fullness of His majesty, while we recognize the Son as visible by reason of the dispensation of His derived existence; even as it is not permitted us to contemplate, the sun, in the full amount of his substance which is in the heavens, but we can only endure with our eyes a ray, by reason of the tempered condition of this portion which is projected from him to the earth."

${ }^{226}$ Throughout this chapter as well as in the subsequent ones, Ph. borrows heavily from Tert. Ad. Prax XIV. Earlier in the same work Tert. explains the appellation Sermonem: hanc Graeci lo\&gon dicunt, quo vocabolo etiam sermonem appellamus: (Ad. Prax. V.3). Thus Sermon is tantamount to Verbum.

${ }^{227}$ Re capitalized ut Spiritum of the CCL text: Ph's point is not to identify the pre-incarnate Christ with the Holy Spirit; rather, he uses the word to emphasize the nature of invisibilis, set in contrast to the earlier corporeus. But it must be noted that in Tert. Ad. Prax. XIV the term refers to the divine nature of Christ. (Footnote \#157 in ANF Vol. 3. Can be found at: http://tertullian.org/anf/anf03/anf03-43.htm\#P10571_2968284 )
} 


\section{Chapter XXI}

XXI. 1. Even the Scriptures testify as to how the invisible God was seen. For it tells us that God was speaking with [Moses] as if speaking to a friend, i.e. face to face. ${ }^{228}$ But then [Moses], in turn, added his request to see [God's] face. Now, if he had [already] seen it, he would not have pressed to see it. 2. Or [think of what] Jacob said: I have seen the Lord face to face, and yet my life was spared. ${ }^{229}$ But how was he preserved while seeing ${ }^{230}$ that face which, if a person sees it, it causes one to fall down dead? And in what manner had the Lord shown his face, when at a later time he said [his face] was not able to be seen? It had to have been under this condition, namely, that it was either in a symbolic representation (aenigmate) or in a dream, or a vision - a point we made earlier. ${ }^{231}$ 3. So this is our conclusion: whenever he was pleased to take upon [himself] this visible disposition (visibilem materiam), [he was also pleased] to continue to be invisible [while] in that state. Indeed, it is necessary to say this. For if we teach that he is visible, then we cannot confess that the One from whom [Christ came] is invisible.

4. But, in order to free myself from this investigation of Old Testament references, I will [next] secure proof of my assertion from the New Testament. For our Lord and God, when he spoke about his Father, said that no one has seen the image of the Father. ${ }^{232}$ Now if the Son himself is the image of the Father (as the Apostle points out), by saying no one has seen the image of the Father, he [actually] denied that he was visible.

5. For that reason he [also] said, You do not know either me or my Father. ${ }^{233}$ This [passage] certainly asserts that there are two who are unknown. Yet even though they

${ }^{228}$ cf. Ex. $33: 11$, Dt. $43: 10$

${ }^{229}$ Gen. 32:30 (NIV's rendering here)

${ }^{230}$ The gerund construction here, quomodo eam faciem videndo salvatus est could grammatically also be rendered: "How was he spared from seeing that face..." (Abl. of separation) implying that Jacob didn't actually see God's face, thus accounting for his preservation.

${ }^{231}$ Ch. XX.2

${ }^{232}$ Jn. 5:37, 1:18

${ }^{233}$ Jn. 8:19 
are two, they also are inseparable. For if they would know him, they also would know the Father, since it was not possible either to know or be ignorant of one without the other on account of their inseparability (per individuitatem). 


\section{Chapter XXII}

XXII. 1. A similar line of logic can be followed when discussing the epithets of "mortal" and "able to suffer." For if the Son neither has a beginning (being as he is the one who always was and is in [the Father], who has no beginning), nor is visible (being the one abides invisible in the bosom of the Father), then he needs to be regarded as being neither "mortal" nor "able to suffer"; he is still God, [sharing] in this part of his substance. $^{234}$

2. For we know that the Spirit of God did not suffer anything, at least in his own name $^{235}$, since God is unable to suffer, and God is Spirit. ${ }^{236}$ We know that [Christ's] entire passion was a suffering of the flesh and soul, that is, suffering as a man. 3. Yet although he suffered in his humanity, he was, nevertheless, also the Son of God, clinging to the Father through that nature from which he had come. Still, while serving as a man on earth, he was preserving (gestabat) the bond of unity; he was not absent from heaven. ${ }^{237}$ For this reason he is called "Mediator," a trustee of both one and the other substance. 4. Since it is impossible for the Spirit of God to suffer, he was permitted to have suffered in his own human [nature], which he did not abandon in his suffering $^{238}$, with the result that he took upon himself the ability to suffer. $\approx$ As was just said, unless this is taken into account, in no way will it even be possible for [Christ's]

234 ex ea tamen substantiae parte qua Deus - lit. "from that part of the substance by which [he is] God."

${ }^{235}$ dumtaxat suo nomine - A strange comment by $\mathrm{Ph}$. Yet it must be remembered that theological arguments / clarifications about the person of the Holy Spirit were yet to come in the history of the Church. The Nicean Creed (325 A.D.) was exceptionally terse in its confession of the Holy Spirit. A major expansion of this Third Article, though, would occur at Constantinople in 381 A.D.

236 Jn. 4:24

${ }^{237}$ nec aberat a caelis - By virtue of his attributes as true God, Ph. points out that even while he was here on earth, Christ was still present in heaven at the same time. In the original Greek, Jn. 3:13 reads:

$\pi$. Yet there is strong manuscript evidence that supports a variant reading for that adds $\pi$ to the end of the sentence.

${ }^{238}$ As Docetism taught.

$\approx$ The original manuscript text for this next sentence is noticeably corrupt, and this translation follows one possible reconstruction as suggested by the editors. 
passion to occur. For if God is viewed in such a way (i.e. capable of suffering), the reasoning of our faith will not stand. But the Arians, evidently assigning such human weakness to him, do not deny that God is [capable of suffering.] 5 . For if it is said that he has a beginning - and it is taught that he is visible and reckoned to be mortal - I don't see what separates him from [any] man, in whom these sort of sufferings dominate. 
XXIII. 1. [Their confession] states: We confess that the Son of God is God from God, Light from Light. This certainly can be viewed as sacrilege, [stated] to vex the perfect profession of the catholic faith with a malicious argument. 2. We dare not overlook [the fact] that something we accept ${ }^{239}$ is [also] something they do not confess (non tenent) along with us. Consequently, we recognize these as the words of the common faith and receive them with the deepest reverence. But what will we do? 3. The mad doctrine of these raving Arians (Arriomanitarum) betrays them; for in saying God from God, Light from Light, [their doctrine] creates another God from God, and another Light from Light. And they do this so that the Son comes from the Father but is not in the Father; so that God is made from God, but is not the only-begotten one who is in God.

4. But more than that, although the writings of some of these men who recently have sent this distinguished [confession of] faith ${ }^{240}$ to us are embraced because they say God from God, Light from Light in them, nevertheless, they have [publicly] taught with heretical arguments that [the Son] is separate from the Father, and excised (excisum) from deep within him.

\footnotetext{
${ }^{239}$ i.e. Not only the wording of the phrase but also the catholic understanding of it.

${ }^{240}$ The $2^{\text {nd }}$ Sirmium Confession ( $7^{\text {th }}$ Arian) had been circulating around Gaul by order of the emperor himself. Cf. Ch. I.1
} 
XXIV. 1. [Their confession] states: That the Son of God himself became man of Mary, through which he has suffered. So they [try to] encompass everything in this agreeable definition (congruo fine) - something they had in mind, something to which they have testified in writing. [But] by giving their own "twist" to it (suo sensui) they also reveal their hidden poisons when they say that the Son of God himself became man of Mary, through which he has suffered. 2. I don't see why they preferred to use the word conpassus (suffered with) instead of just frankly (libere) confessing he was passibilis (able to suffer), as if he "suffered with" something rather than just "he suffered."241 Again, if God is incapable of suffering, then he certainly is incapable of suffering with [something/one.] For he neither "suffered with" nor suffered, at least in his divine nature..$^{242}$

3. So says the Apostle: He suffered through weakness ${ }^{243}$, undoubtedly in the flesh. For the flesh is weak, the spirit willing. ${ }^{244}$ But he lives by the power (virtute) of God ${ }^{245}$, indeed, [he lives] through himself. For he himself is the power of God ${ }^{246}$, having life within himself. We believe that our Lord consisted of two substances, both the human and the divine. Thus he possessed divine immortality even as he was mortal according to his humanity. He was born through the one, but brought forth (prolatus) through the other. Through the one he is immortal, but through the other he was mortal. 4. The same Apostle stated: Christ died ${ }^{247}$, that is, [died] as the "anointed One." To be sure, he was

\footnotetext{
${ }^{241}$ Perhaps Ph. is suspicious of that word because Tert. (Ad. Prax. XXIX.5) has specifically stated: ergo nec compassus est pater filio.

242 ex ea tamen conditione qua Deus - lit. "in that condition, at least, by which [he is] God."

${ }^{243} 2$ Co. 13:4, yet the Vulgate has crucifixus est for passus here.

${ }^{244}$ Mt. 26:41

${ }^{245} 2$ Co. 13:4

${ }^{246} 1$ Co. $1: 18$

${ }^{247} 1$ Co. 15:3
} 
given this name ${ }^{248}$ at his anointing. But if nothing more than his flesh was anointed, then it should only be stated that [he died] according to his mortal flesh. Yet many times it simply says, "Christ died."249

\footnotetext{
248 i.e. "Christ" ("the Anointed One")

${ }^{249} \mathrm{Ph}$. plunges into deep dogmatic theology here, touching upon the communicatio idiomatum. Specifically, in reference to using the divine title "Christ" with a mortal activity ("died"), cf. Mueller: "The qualities of each nature (idiomata) belong to the person of Christ, but each nature retains its own idiomata, so that the qualities of one nature do not, according to the genus idiomaticum, become the qualities of the other. (Dictionary of Greek and Latin Theological Terms. Grand Rapids: Baker Books, 1985. p. 73) Ph.'s main point in this chapter seems to be this: if the Arians - for whatever reason - employ the term conpassus, they are muddying the waters by 1) not using conventional terminology that everyone understands and 2) opening the door for patripassionism, keying off the word "with." Ph. follows St. Paul, who says passus est. "The two natures are here considered as joined in the person, and the interchange of attributes is understood as taking place at the level of the person and not between the natures. This view was typical of the Antiochene Christology..." (Mueller, op.cit. p. 72)
} 


\section{Chapter XXV}

XXV. 1. But if anyone wishes to force out something different from these two [concepts] so that either we limit the number of God to one (if in our confession we say "one"), or we openly profess that there are two Gods (if we say that both the Father and the Son are God) - [if anyone wishes to force out something different], let them know this before anything else: we do not prefer ${ }^{250}$ to say either "one" or "two", because we state it this way: "one [God] in two [persons], terminology our Lord himself supplied when he said, I and the Father are one. ${ }^{251}$ [He said this] so that we would believe there are two [persons] in one power (virtute). 2. He did not speak as if the Father and the Son were only one person, or as if the Son was asserting that he himself was the Father -[something like] "I am my Son," or "Today I have begotten myself."252 [Nor did he say something like,] "I have begotten myself before light was brought forth (ante luciferum), ${ }^{253 "}$ or "The Lord established me at the beginning of my ways, he poured me out before all ages."254 [Nor did he say,] "I am the one Father." 3. But [the Son], supplying us with the knowledge that this [description] is by a sacramental distinction ${ }^{255}$, not by a division of persons, said: I am in the Father, and the Father is in

\footnotetext{
${ }^{250}$ cum praeiudicio - This is the third time Ph. employs this legal term, used in reference to judgments made in court - a "precedent" or simply "judgment." Negatively, it can mean "prejudice," and it seems to have a hint of that nuance here.

${ }^{251}$ Jn. 10:30

${ }^{252}$ Ref. to Ps. 2:7, a passage long held to refer to the eternal generation of the Son from the Father.

${ }^{253}$ Overtones of Ps. 109 (110):3, "from the womb of dawn" (NIV)

${ }^{254}$ Overtones again of Prov. 8:22. But key here is Ph.'s use of Dominus instead of Deus, implying that the Son is the speaker of this passage.

${ }^{255}$ sacramenti distinctione - cf. Tert. Ad. Prax. 12.6: "But how you must understand "another" I have already professed, in the sense of person, not of substance, for distinctiveness, not for division." (Evans translation, 1948. Found at www.tertullian.org . ) By "sacramental distinction," Ph. probably does not have in mind a eucharistic or baptismal distinction, but rather uses the term sacramentum in the sense that the Vulgate uses it, as a translation of the Greek mysterion, i.e. something that is unknown to human beings and cannot be known without God's revelation. Alternatively, the term sacramentum also can be used in the sense of "the ministry." The phrase could also be rendered, then, "on the basis of a difference in ministry" - a thought which is not out of line with the argument here.
} 
For when one sees the Son, he sees the true image of the Father and the representation ${ }^{259}$ formed (expressa) of his substance. He is the Discourse (Word) of God, not [merely] the sound of his voice; he is [God's] substance itself, having that substance in a bodily form. ${ }^{260}$ He does not exist without this substance, because he proceeded from such a substance and produced (fecit) such substances. ${ }^{261}$

\section{Thus nothing empty can come from fullness, nothing incomplete can come} from completeness; [Christ] ${ }^{262}$ the Word of God was furnished by the Spirit of God, ${ }^{263}$ and, to say it more clearly, the body of the Word is the Spirit. For the body is spirit, but a body of its own kind. ${ }^{264}$ Spirit is both invisible and incomprehensible. 6. Now was God ever an empty and void "thing" (res) $?^{265}$ [Of course not]. For God is spirit. ${ }^{266}$ Or again, No one knows the things that are in God except the Spirit himself who is in him. ${ }^{267}$ Indeed, we read: Who has known the mind of the Lord, or who was his advisor? ${ }^{268}$ Certainly no one, apart from his own Spirit. 7. With good reason (nec inmerito) the prophet calls

\footnotetext{
256 Jn. 14:10

257 Jn. 10:30

258 Jn. $14: 9$

$259 \mathrm{cf}$. Heb. 1:3, where figura is used in this sense.

${ }^{260}$ Col. 2:9 quia in ipso inhabitat omnis plenitudo divinitatis corporaliter

${ }^{261}$ CCL textual apparatus suggests qui tantas substantias fecit as a ref. to Christ, "through whom all things were made" (Jn.1:3). Cf. also Tert. Ad. Prax. 7.7: "I, on the contrary, contend that nothing empty and void could have come forth from God, seeing that it is not put forth from that which is empty and void; nor could that possibly be devoid of substance which has proceeded from so great a substance, and has produced such mighty substances: for all things which were made through Him, He Himself (personally) made." (Holmes translation, 1870, in $A N F 3$. At Www.tertullian.org )

${ }^{262}$ Migne's addition, in order to complement instructus est, since Sermo cannot agree gramatically.

${ }^{263}$ quia Dei Sermo Spiritu Dei instructus est - The chiasm could identify Sermo with Spiritu, a thought Ph. will introduce next. Here, though, is a pure exegetical question; Spiritu could express agency, a thought consistent with Mt.'s description of the Son's conception (Mt.1:20). On the other hand, Spiritu could also express instrumentality, since the Son is described as one who had the fullness of the Spirit (Is. 11:2;61:1; Lk. 4:1, 14, 18).

264 cf. Footnote \#184. Also cf. Tert. Ad. Prax. 7.8, where the terminology is virtually the same.

${ }^{265}$ Numquid - expects negative response. Also, copious textual notes here indicate that the manuscript tradition isn't clear as to Ph.'s line of thought here, esp. with the exact thrust of res. The context would indicate that res is being set in contrast to spiritus.

${ }^{266}$ Jn. 4:24 - cf. also Hilary's discussion of this passage in De. Trin. II.31.

${ }^{267} 1$ Co. $2: 11$

${ }^{268}$ Ro. $11: 34$
} 
the Spirit the "skilled craftsman" and "wonderful counselor."269 For this same Word of the Spirit is also the Wisdom of God. ${ }^{270}$ And about this person Solomon wrote: When he prepared heaven, I was there with him. ${ }^{271}$ Again, I was with him, and he was rejoicing in me. 272 So there was no other counselor, since through him all things were made that have been made. ${ }^{273}$ 8. And since this same Wisdom is also both the Word and the Spirit of God, his appointed tasks (officia) are related [to us] with [various] individual names. "Wisdom" was at the Father's side (aderat Patri) as he was establishing all things. ${ }^{274} B y$ his "Word" were the heavens made firm, and by the "Spirit" of his mouth all their powers. ${ }^{275}$ Therefore, it is apparent that he has come as one in the same; in this place (nunc) [he comes] under the name "Spirit"; in another, under the epithet "Discourse (Word)"; in a third, with the title "Wisdom." 276

${ }^{269}$ sapientem architectum - cf. Is. 3:3. admirabilem consiliarum -cf. Is. 9:6. But the latter ref. is unexpected, as this passage had been long held as messianic. But is Ph. thinking of Spiritus as being the Holy Spirit or is he using the term in the same way as Tertullian, i.e. as a reference to the divine nature of Christ.? Arguing (as he is) in this chapter about the concept of "one God in two persons," it appears $\mathrm{Ph}$. is using Spiritus primarily in the manner of Tertullian. (cf. fn. \#184)

${ }^{270} \mathrm{Ph}$. follows Tert. Ad. Hermog. 18.1 here: If any material was necessary to God in the creation of the world, as Hermogenes supposed, God had a far nobler and more suitable one in His own wisdom -one which was not to be gauged by the writings of philosophers, but to be learnt from the words or prophets. This alone, indeed, knew the mind of the Lord. For "who knoweth the things of God, and the things in God, but the Spirit, which is in Him? " Now His wisdom is that Spirit. This was His counsellor, the very way of His wisdom and knowledge. Of this He made all things, making them through It, and making them with It." (Holmes translation from $A N F 3,1870$. At www.tertullian.org)

${ }^{271}$ Prov. 8:30. " Then I was the craftsman at his side. I was filled with delight day after day, rejoicing always in his presence," (NIV)

272 Ibid.

${ }^{273}$ Jn. 1:3

274 cf. Prov. 8:30

${ }^{275}$ Ps. 32:6. virtus here in the Vg. for the Hebrew tsva-oth (Sabbaoth) - "hosts, armies"

${ }^{276} \mathrm{cf}$. Tert. Ad. Prax. $7.3 \mathrm{ff}$ : For if indeed Wisdom in this passage seems to say that She was created by the Lord with a view to His works, and to accomplish His ways, yet proof is given in another Scripture that "all things were made by the Word, and without Him was there nothing made; " as, again, in another place (it is said), "By His word were the heavens established, and all the powers thereof by His Spirit" -that is to say, by the Spirit (or Divine Nature) which was in the Word: thus is it evident that it is one and the same power which is in one place described under the name of Wisdom, and in another passage under the appellation of the Word, which was initiated for the works of God which "strengthened the heavens; " "by which all things were made," "and without which nothing was made." Nor need we dwell any longer on this point, as if it were not the very Word Himself, who is spoken of under the name both of Wisdom and of Reason, and of the entire Divine Soul and Spirit. He became also the Son of God, and was begotten when He proceeded forth from Him." (Holmes translation, 1870, in ANF 3. At

www.tertullian.org ) 


\section{Chapter XXVI}

XXVI. 1. Therefore this Discourse (Word), since he is the form of God $^{277}$ furnished (constructus) with wisdom and reason - and by the Spirit's wisdom and reason - that is, possessing the power of God in its entirety, did not equate himself with God the Father, but taking the form of a servant he humbled himself even to death. ${ }^{278}$ 2. He put on [a form that] was able to serve, that was able to die; he took on a human nature. This human nature was raised up (excitatus) ${ }^{279}$ and offered to heaven so that this "second Adam" could restore through his obedience what the first [Adam] had lost through his transgression. ${ }^{280}$ 3. On this point, if anyone asks the Apostle about [the Son's] lordly state, that is, about his dual nature in a singular substance (which was joined by nature to his own Source (auctori suo)) -- [if anyone asks,] let him hear briefly (ad compendium $)^{281}$... what this same Apostle perceived when he spoke of God the Father: How unsearchable are his ways ${ }^{282}$ and the secret things hidden in the past (retro). ${ }^{283} \quad$ 4. From him and through him and to him are all things. ${ }^{284}$ Now when he says through him, to me this indicates the Son. For I read, through him are all things. When [the Apostle] says, $\underline{\text { in }}$ him, that's nothing new. For they have established ${ }^{285}$ the very beginnings of all sources of life (seminum) [as being] in him. And the phrase from him certainly refers to the Father, who is regarded as the source of all things. 5. But if that's the case, how will

\footnotetext{
${ }^{277}$ Php. 2:6

${ }^{278}$ Php. 2:6-7

279 Jn. $3: 14$ ?

${ }^{280}$ cf. 1 Co. 15:21-22, 45; Ro. 5:12-17

${ }^{281}$ Some sentences of the original text are missing at this point.

${ }^{282}$ Ro. 11:33

${ }^{283}$ Eph. 3:9

${ }^{284}$ Ro. $11: 36$

${ }^{285}$ The $3^{\text {rd }}$ pl. constituerunt probably refers to the Arian viewpoint; they also accepted that God the Father is the source of everything. Thus this point is "nothing new." Initia could be N. Pl, but is would be unusual to distinguish a Greek middle sense without the usual reflexive pronoun.
} 
his $^{286}$ reasoning stand as lucid (distincta) if these [two concepts] are joined together, that is, by attributing all things to one? For there [clearly] is one from whom are all things and then [there is] another one through whom are all things, the one [referring to] the unborn One and the other being the only-begotten One. He can only state both things are correct under this condition: on the one hand all things are from the Son, as $(d u m)^{287}$ by nature he is in the heart of the one from whom come all things; and, on the other hand, all things are through the Father, as (dum) the one through whom and in whom are all things is always within him. ${ }^{288}$ For the Father acts in his mind (sensu agit); and the Son, to be sure, who is in the Father's mind, does what he sees. ${ }^{289}$ 6. So we should not believe that the Apostle stated this rashly. Rather we should trust that he believed this, namely, that the Son of God was made, in respect to his flesh, something he was not;; and that in respect to the spirit he truly was what he had been, since he has to be that which he always was. ${ }^{290}$

\footnotetext{
${ }^{286}$ i.e. Paul's

${ }^{287} d u m$ - Not a specifically temporal nuance, but more "all the while as".

${ }^{288}$ Note Ph.'s clever metathesis: he had begun the paragraph by saying that the phrase per ipsum referred to the Son, but here attributes ex ipso to the Son and per ipsum to the Father to underscore the mutual indwelling and complete permeation of the one with the other.

${ }^{289}$ Overtones of Jn. 5:19 - "I tell you the truth, the Son can do nothing by himself; he can do only what he sees his Father doing, because whatever the Father does the Son also does." cf. Tert. Ad. Prax. 15.9: "For the Father acts by mind and thought; whilst the Son, who is in the Father's mind and thought, gives effect and form to what He sees. Thus all things were made by the Son, and without Him was not anything made." (Holmes translation from ANF 3, 1870. At www.tertullian.org )

${ }^{290}$ cf. Hil. De Trin. II.17 : "The Word could not be other than He was; that was is unconditional and unlimited." ( NPNF Vol. 2, from the Christian Classics Ethereal Library, www.ccel.org )
} 


\section{Chapter XXVII}

XXVII. 1. Therefore, we need to firmly hold to this doctrine (ratio) as it crawls along a steep and narrow path, with rugged places encompassing it on this side and that. [Seemingly] level and easy-to-travel (facilia) places rise up below, but ${ }^{291}$ they are obscured by devilish deceit so that they plunge [men] into the ruin of death. 2. For if we label the one God as a singular person (singulariter), excluding any terminology of a second person, [in essence] we are approving the madness of that heresy which defends [the belief] that the Father himself suffered. And if we admit that [our] number [is arrived at] by separating the two (cum divisione), then we are linked to the Arians, who make a new God from God and defend [the belief] that his substance was formed out of nothing.

3. ${ }^{292}$ Therefore, as we have said, we need to hold on to the rule of faith (regula) which confesses that the Son is in the Father, and the Father is in the Son; this retains [the truth] that [the Son] is one substance in two persons, yet acknowledges this arrangement of divinity. Thus the Father is God and the Son is God, since God the Son is within God the Father.

4. If anyone is offended at this, let him also hear us say that the Spirit is from God, since [God] not only has a second person in the Son, but also a third [person] in the Holy Spirit. Our Lord speaks to this: I will ask of my Father and he will give you another Counselor. $^{293}$ 5. Just as another - the Son - comes from the Father, so also another - the Spirit - comes from the Son. And just as the Son is the second person [of the Godhead],

\footnotetext{
${ }^{291}$ Manuscript $D u$ omits the relative quae at this point, and I have followed that suggestion.

292 The only portion of Ph. that I have found translated into English begins at this point and concludes Ch. 27 (Ch. 22 in Migne). It is found in Jurgens, W. The Faith of the Early Fathers, Vol. 1. Collegeville: The Liturgical Press, 1970. p. 391.

${ }^{293}$ Jn. 14:16
} 
so also the Spirit is the third. Nevertheless, the sum (omnia) is one God, because the three are one.

6. This [truth] we believe, this [truth] we hold fast, because we have received it from the prophets. This is what that the Gospel writers have spoken to us. This is what the Apostles handed down to us, and this is what the martyrs confessed in the throes of their suffering (in passione). And we also cling to this [truth] with minds [controlled] by faith. Even if an angel from heaven should preach against it, let him be condemned. ${ }^{294}$

${ }^{294}$ Gal. 1:8 


\section{Chapter XXVIII}

XXVIII. 1. But even with all these [arguments of theirs] shattered and cast into the light of public knowledge, I am not unaware that the name of Hosius ${ }^{295}$, that most elderly priest who always had such resolute faith, is now tempered to serve as a battering ram, one might say, against us in order to drive away the [seeming] rashness of our objections. But I have penned this rather brief tract in response to those engineering such a device against us.

2. [Hosius'] authority is unable to compel us, because either he is in error now or he has always been in error. Yet the world knows what he has firmly held throughout his life (in hanc aetatem) - what staunchness (constantia) attended him at Serdica ${ }^{296}$ and in the discussions at Nicea, and how he condemned the Arians. 3. How [can his authority compel us] if he now holds different [opinions], and defends whatever things he condemned in the past while condemning the things he once defended? I'll say it again: I will not be compelled by his authority. 4. If for nearly ninety years he believed wrongly, I won't believe that [suddenly] after ninety years he believes correctly. Or, if now he believes the right thing, what are we to think about those items he defined as [truths] of the faith which he himself [professed] at that time, things that have stood the test of time (de saeculo transierunt)? And what should we publicly say about him, if he had been careless (dormisset) [when brought] before this synod ${ }^{297}$

\footnotetext{
${ }^{295}$ Hosius of Cordova, one of the prime architects of the Nicene Symbol and staunch defender of Athanasius throughout his life, may have lived to be 102. Even here, in this final chapter, Ph. himself states that he is over ninety years old (XXVIII.4). In the closing days of his long life Hosius was summoned to Milan by the emperor and forced to sign the Second Sirmium Confession and, subsequently, his name was misused; "the second Sirmium formula was published as the formula of Hosius (www.newadvent.org, re 'Hosius.')" Athanasius in De Syn. characterized the entire episode as a momentary lapse of a tired, old man, who in spite of the events which took place remains worth of veneration.

${ }^{296}$ Hosius presided at the Council of Serdica (343 A.D.) which soundly condemned the Arians.

${ }^{297}$ i.e. the second synod of Sirmium (357 A.D.) at which Hosius was pressured into signing the "blasphemy."
} 
5. So, as we stated above, the authority of his "official"298 judgment carries no weight because it takes a stand against itself. ${ }^{299}$ How true it is what we read: The righteousness of a righteous man will not save him on that day he wanders away. ${ }^{300}$ Amen.

\footnotetext{
${ }^{298}$ Here again Ph. uses the judicial term praeiudicium. The nuance of "prejudiced judgment" could also be an acceptable rendering here.

299 i.e. Hosius' new "authoritative opinion" contradicts the authoritative opinions that he had been expressing throughout his entire lifetime, up to this point. Although Ph. seems to be skeptical of Hosius' sudden change of heart (cf. XXVIII.4), nevertheless he must take a stand against what Hosius - pressured or not - has given his stamp of approval to.

${ }^{300}$ Eze. 33:12
} 


\section{Appendix 1: Arian Confessions}

\section{Sixth Arian Confession aka First Sirmium (Sirmium, 351 AD)}

We believe in One God, the Father Almighty, the Creator and Maker of all things, from whom all fatherhood in heaven and earth is named;

And in His Only-begotten Son, our Lord Jesus the Christ, who before all the ages was begotten from the Father, God from God, Light from Light, by whom all things were made, in heaven and on the earth, visible and invisible, being Word and Wisdom and True Light and Life, who in the last of days was made man for us, and was born of the Holy Virgin, and crucified and dead and buried, and rose again from the dead the third day, and was taken up into heaven, and sat down on the right hand of the Father, and is coming at the consummation of the age, to judge quick and dead, and to render to every one according to his works; whose Kingdom being unceasing endures unto the infinite ages; for He shall sit on the fight hand of the Father, not only in this age, but also in that which is to come.

And in the Holy Ghost, that is, the Paraclete; which, having promised to the Apostles to send forth after His ascension into heaven, to teach and to remind them of all things, He did send; through whom also are sanctified the souls of those who sincerely believe in Him.

(1.) But those who say that the Son was from nothing or from other subsistence and not from God, and that there was time or age when He was not, the Holy and Catholic Church regards as aliens.

(2.) Again we say, Whosoever says that the Father and the Son are two Gods, be he anathema.

(3.) And whosoever, saying that Christ is God, before ages Son of God, does not confess that He has sub-served the Father for the framing of the universe, be he anathema.

(4.) Whosoever presumes to say that the Ingenerate, or a part of Him, was born of Mary, be he anathema.

(5.) Whosoever says that according to foreknowledge the Son is before Mary and not that, generated from the Father before ages, He was with God, and that through Him all things were originated, be he anathema.

(6.) Whosoever shall pretend that the essence of God is dilated or contracted, be he anathema.

(7.) Whosoever shall say that the essence of God being dilated made the Son, or shall name the dilation of His essence Son, be he anathema. 
(8.) Whosoever calls the Son of God the mental or pronounced Word, be he anathema.

(9.) Whosoever says that the Son from Mary is man only, be he anathema.

(10.) Whosoever, speaking of Him who is from Mary God and man, thereby means God the Ingenerate, be he anathema.

(11.) Whosoever shall explain "I God the First and I the Last, and besides Me there is no God," (Is. 44:6), which is said for the denial of idols and of gods that are not, to the denial of the Only- begotten, before ages God, as Jews do, be he anathema.

(12.) Whosoever hearing "The Word was made flesh," (John 1:14), shall consider that the Word has changed into flesh, or shall say that He has undergone alteration by taking flesh, be he anathema.

(13.) Whosoever hearing the Only-begotten Son of God to have been crucified, shall say that His Godhead has undergone corruption, or passion. or alteration, or diminution, or destruction, be he anathema.

(14.) "Whosoever shall say that Let Us make man" (Gen 1:26), was not said by the Father to the Son, but by God to Himself, be he anathema.

(15.) Whosoever shall say that Abraham saw, not the Son, but the Ingenerate God or part of Him, be he anathema.

(16.) Whosoever shall say that with Jacob, not the Son as man, but the Ingenerate God or part of Him, has wrestled, be anathema.

(17.) Whosoever shall explain, "The Lord rained fire from the Lord" (Gen 24:24), not of the Father and the Son, and says that He rained from Himself, be he anathema. For the Son, being Lord, rained from the Father Who is Lord.

(18.) Whosoever, hearing that the Father is Lord and the Son Lord and the Father and Son Lord, for there is Lord from Lord, says there are two Gods, be he anathema. For we do not place the Son in the Father's Order, but as subordinate to the Father; for He did not descend upon Sodom without the Father's will, nor did He rain from Himself, but from the Lord, that is, the Father authorising it. Nor is He of Himself set down on the fight hand, but He hears the Father saying, "Sit Thou on My right hand" (Psalm 110:1).

(19.) Whosoever says that the Father and the Son and the Holy Ghost are one Person, be he anathema.

(20.) Whosoever, speaking of the Holy Ghost as Paraclete, shall mean the Ingenerate God, be he anathema.

(21.) Whosoever shall deny, what the Lord taught us, that the Paraclete is other than the Son, for He hath said, "And another Paraclete shall the Father send to you, whom I will ask," (John 14:16) be he anathema. 
(22.) Whosoever shall say that the Holy Ghost is part of the Father or of the Soul be he anathema.

(23.) Whosoever shall say that the Father and the Son and the Holy Ghost are three Gods, be he anathema.

(24.) Whosoever shall say that the Son of God at the will of God has come to be, as one of the works, be he anathema.

(25.) Whosoever shall say that the Son has been generated, the Father not wishing it, be he anathema. For not by compulsion, led by physical necessity, did the Father, as He wished not, generate the Son, but He at once willed, and, after generating Him from Himself apart from time and passion, manifested Him.

(26.) Whosoever shall say that the Son is without beginning and ingenerate, as if speaking of two un-begun and two ingenerate, and making two Gods, be he anathema. For the Son is the Head, namely the beginning of all: and God is the Head, namely the beginning of Christ; for thus to one unbegun beginning of the universe do we religiously refer all things through the Son.

(27.) And in accurate delineation of the idea of Christianity we say this again; Whosoever shall not say that Christ is God, Son of God, as being before ages, and having subserved the Father in the framing of the Universe, but that from the time that He was born of Mary, from thence He was called Christ and Son, and took an origin of being God, be he anathema.

(Athanasius, De Synodis, 27. LPNF, ser. 2, vol. 4, 464-465).

\section{Seventh Arian Confession aka Second Sirmium (Sirmium, 357 AD).}

Whereas it seemed good that there should be some discussion concerning faith, all points were carefully investigated and discussed at Sirmium in the presence of Valens, and Ursacius, and Germinius, and the rest.

It is held for certain that there is one God, the Father Almighty, as also is preached in all the world.

And His One Only-begotten Son, our Lord Jesus Christ, generated from Him before the ages; and that we may not speak of two Gods, since the Lord Himself has said, "I go to My Father and your Father, and My God and your God" (John 20:17). On this account He is God of all, as also the Apostle taught: "Is He God of the Jews only, is He not also of the Gentiles? yea of the Gentiles also: since there is one God who shall justify the circumcision from faith, and the uncircumcision through faith" (Rom 3:29-30); and every thing else agrees, and has no ambiguity.

But since many persons are disturbed by questions concerning what is called in Latin "Substantia," but in Greek "Usia," that is, to make it understood more exactly, as to 
"Coessential," or what is called, "Like- in-Essence," there ought to be no mention of any of these at all, nor exposition of them in the Church, for this reason and for this consideration, that in divine Scripture nothing is written about them, and that they are above men's knowledge and above men's understanding; and because no one can declare the Son's generation, as it is written, "Who shall declare His generation? for it is plain that the Father only knows how He generated the Son, and again the Son how $\mathrm{He}$ has been generated by the Father. And to none can it be a question that the Father is greater for no one can doubt that the Father is greater in honour and dignity and Godhead, and in the very name of Father, the Son Himself testifying, The Father that sent Me is greater than I" (John 10:29, Ib. 14:28). And no one is ignorant, that it is Catholic doctrine, that there are two Persons of Father and Son, and that the Father is greater, and the Son subordinated to the Father together with all things which the Father has subordinated to Him, and that the Father has no beginning, and is invisible, and immortal, and impassibly; but that the Son has been generated from the Father, God from God, Light from Light, and that His origin, as aforesaid, no one knows, but the Father only. And that the Son Himself and our Lord and God, took flesh, that is, a body, that is, man, from Mary the Virgin, as the Angel preached beforehand; and as all the Scriptures teach, and especially the Apostle himself, the doctor of the Gentiles, Christ took man of Mary the Virgin, through which He has suffered. And the whole faith is summed up, and secured in this, that a Trinity should ever be preserved, as we read in the Gospel, "Go ye and baptize all the nations in the Name of the Father and of the Son and of the Holy Ghost" (Matt. xxviii. 19). And entire and perfect is the number of the Trinity; but the Paraclete, the Holy Ghost, sent forth through the Son, came according to the promise, that He might teach and sanctify the Apostles and all believers.

(Athanasius, De Synodis, 28. LPNF, ser. 2, vol. 4, 466). 